\title{
Sedimentology and reservoir properties of tabular and erosive offshore transition deposits in wave-dominated, shallow-marine strata: Book Cliffs, USA
}

\author{
Christian Haug Eide ${ }^{1,2, *}$ John A. Howell ${ }^{1,3}$ and Simon J. Buckley ${ }^{1}$ \\ ${ }^{1}$ Uni CIPR, P.O. Box 8710, 5020 Bergen, Norway \\ ${ }^{2}$ Department of Earth Science, University of Bergen, P.O. Box 7803, 5020 Bergen, Norway \\ ${ }^{3}$ School of Geosciences, University of Aberdeen, Rm 106, Meston Building, Rm 106, Meston Building, \\ Aberdeen, AB24 3UE, Scotland \\ *Corresponding author (e-mail: Christian.eide@uni.no) \\ Running head: Erosive offshore transition zone, Book Cliffs, USA
}

Keywords: reservoir modelling, permeability, shoreface, reservoir properties, reservoir prediction, outcrop analogue

Submitted to: Petroleum geoscience 21 January 2014

Revised version submitted 28 October 2014.

This is a postprint, published version here: http://dx.doi.org/10.1144/petgeo2014-015

\begin{abstract}
Facies models for wave-dominated shorelines include an "offshore transition zone" between shelfal mudstones and nearshore shoreface sandstones. Offshore transition zone deposits are commonly tabular sandstone beds interbedded with continuous mudstone beds. However, observations from the Blackhawk Formation show that the offshore transition zone locally consists of erosive-based sandstone beds with "pinch-and-swell" geometries containing steep-walled gutter-casts, in areas larger than $6 \times 2 \mathrm{~km}$ along strike and dip. This increases the amount of sand-on-sand-contacts, and leads to improved vertical permeability. Predicting the distribution of erosive offshore transition within the subsurface is therefore desirable.

In this study, offshore transition zone deposits have been studied using virtual outcrops. Tabular offshore transition zone deposits have continuous sandstone and mudstone beds much longer than $500 \mathrm{~m}$, and erosive offshore transition zone deposits have discontinuous shales on average $60 \mathrm{~m}$ long. Reservoir modelling shows a 10-3 times increase in vertical permeability in erosive compared to tabular offshore transition deposits, the magnitude decreasing with increasing fraction of shale.

Erosive offshore transition deposits occur near distributary channels, subaqueous channels and abrupt bathymetric breaks. A regional study shows that erosive offshore transition zone deposits are mainly developed where parasequences prograde into deeper water offshore the platform break of the preceding parasequence, are commonly associated with basinal turbidites, and may be related to erosion by bypassing turbidity currents.
\end{abstract}




\section{Introduction}

Wave-dominated, shallow marine deposits are important hydrocarbon reservoirs (e.g. Galloway et al. 2000; Husmo et al. 2003; Ainsworth 2005) and are typically less heterogeneous than their tide- and river-dominated counterparts (MacDonald \& Aasen 1994; Howell et al. 2008, Manzocchi et al. 2008). Commonly used facies models (e.g. Elliott 1978; Howell and Flint 2003, Clifton 2006) of such deposits define regressive packages formed during a single phase of shoreline progradation as parasequences (Van Wagoner et al. 1990). Within a single parasequence there is a simple succession consisting of five shoreline-parallel facies belts: (1) shelfal "offshore" mudstones, grading into (2) tabular, interbedded sandstone and mudstone beds of the "offshore transition zone" (the term distal lower shoreface is also used by some authors), to (3) amalgamated hummocky-cross-bedded sandstone beds of the "lower shoreface", to (4) amalgamated cross-bedded sandstone beds of the "upper shoreface". This succession is capped by (5) low-angle to planar parallel stratified sandstone beds, often rooted, and interpreted as beach or "foreshore" deposits, which may be overlain by coals. While this model is robust as a general description and has predictive power in subsurface settings (Hodgetts et al. 2001; Bullimore \& Helland-Hansen 2009; Went et al. 2013), significant complexity and variability exists on the intra-parasequence scale and within the individual facies belts. Intraparasequence complexities $n$ such deposits include the presence of bedsets, which are upwardcoarsening discontinuities related to minor sea-level fluctuations or variations in climate or sediment supply (Storms \& Hampson 2005; Sømme et al. 2008), the presence of river-dominated deltaic intervals within an otherwise wave-dominated shoreface (Hampson \& Storms 2003; Charvin et al. 2010; Ainsworth et al. 2011; Eide et al. 2014) or the presence of discontinuous mudstone beds within shoreface sandstones (Eide et al. 2014).

The offshore transition zone (OTZ) facies association is the focus of this article. The OTZ is a heterolithic succession comprising sandstone beds deposited by occasional storms interbedded with mudstones deposited from suspension during fair weather periods (Dott \& Bourgeois 1982; Myrow \& Southard 1996; Dumas \& Arnot 2006). The beds are commonly described as tabular (Elliott 1978; Howell \& Flint 2003), but several workers have reported localized intervals where the offshore transition contains abundant erosive gutter casts, and where sandstone beds pinch and swell significantly both along strike and down depositional dip (Brenchley et al. 1986; Plint 1991; Hadley \& Elliott 1993; Van Wagoner 1995; Pattison et al. 2007). In this paper, two types of OTZ are distinguished: "Tabular OTZ" (OTZt) in which the beds are tabular and laterally continuous, and "erosive OTZ" (OTZe) in which the sandstone beds are lenticular to undulating and associated with numerous, erosive gutter casts. Previous authors have interpreted the occurrence of OTZe as a response to falling relative sea-level and sediment bypass (e.g. Plint 1991; Hadley \& Elliott 1993), but not all occurrences of erosive offshore transition are associated with obvious forced regressive intervals.

The presence of gutter casts in the shallow-marine parts of the Campanian Blackhawk Formation of Central Utah has been noted by several authors (Van Wagoner 1995; Hampson 2000; Pattison et al. 2007). Furthermore, large numbers of interpreted turbidite shelf lobes and turbidite filled channels have recently been identified in the basin (Pattison et al. 2007; Hampson 2010). While it has been suggested that gutter casts may be a useful proxy for predicting down-dip occurrence of turbidites on the inner shelf (Pattison et al. 2007), no detailed descriptions of models for their genesis exist. The recognition and predicted distribution of OTZe, over the more common OTZt, is important because 
there is a sharp permeability contrast between the better reservoir quality sandstones and the poor reservoir quality mudstones. The geometry of the beds control the vertical permeability of the facies, which will be very low if the beds are tabular (low $\mathrm{K}_{\mathrm{v}} / \mathrm{K}_{\mathrm{h}}$ ratio) but higher if there mudstones are eroded, leading to sand-on-sand contacts (higher $\left(\mathrm{K}_{\mathrm{v}} / \mathrm{K}_{\mathrm{h}}\right.$ ratio). This has the potential to dramatically alter the flow properties of such facies in hydrocarbon reservoirs.

The objectives of this paper are fivefold: (1) To describe offshore transition deposits with special reference to the OTZe; (2) to document occurrence of OTZe versus OTZt in the study area; (3) to document bed geometries in tabular and erosive offshore transition deposits; (4) to quantify how reservoir properties vary in tabular and erosive offshore transition deposits; and finally (5) to discuss possible mechanisms for formation of erosive offshore transition and propose a predictive model for their occurrence in other systems.

\section{Geological background}

The studied deposits are exposed in the Book Cliffs of central Utah, USA (Fig. 1), and are part of the Campanian Blackhawk Formation (Fig. 2; Young 1955). The formation is part of a clastic wedge which prograded into the retro-arc foreland basin of the Sevier Orogen, a result of subduction on the western side of the North American plate, leading to the accretion of terranes and development of the Sevier mountain chain (Kauffman \& Caldwell 1993). This foreland basin was part of the Western Interior Seaway, which developed at a time of very high sea-level during the Cretaceous (Haq et al. 1988). The sediment source was the uplifting Sevier Mountains to the east, and the depositional system comprised an alluvial plain with distributive fluvial systems that fed the wave-dominated Blackhawk shorelines (Howell \& Flint 2003; Rittersbacher et al. 2014; Hampson et al. 2013). The stratal architecture of the Blackhawk Formation illustrates large scale progradation under a longterm rise in relative sea-level (Howell \& Flint 2003). The shallow-marine part of the Blackhawk Formation has been subdivided into six, mainly progradational, tongues named the Spring Canyon, Aberdeen, Kenilworth, Sunnyside, Grassy and Desert members (Fig. 2; Young 1955), which are separated by regional flooding surfaces and landward facies belt shifts greater than $10 \mathrm{~km}$ (Young 1955; Hampson \& Howell 2005; Hampson 2010). The members are further divided into parasequences, progradational sandstone tongues deposited under a single shoreline transit, separated by flooding surfaces developed during smaller transgressions on the scale of a few kilometers (Fig. 2; Van Wagoner et al. 1990; Hampson \& Howell 2005).

The age of the Blackhawk Formation has been constrained to between 82.5 and $79 \mathrm{Ma}$ based on radiometric and palaeontological data (Fouch et al. 1983). Each member therefore represents an approximate duration of about 0.5-0.6 Ma. Each parasequence is estimated to represent 70-120 ka (Hampson \& Storms 2003; Howell \& Flint 2003).

The study area includes the excellent exposures of the western and southern face of the Beckwith Plateau between Woodside Canyon and Battleship Butte (Fig. 1), which exhibit outcrops of Kenilworth parasequences K3 and K4 (sensu Taylor \& Lovell 1995; see also Pattison 1995; Hampson \& Storms 2003), Sunnyside parasequences S2 and S3 (Howell \& Flint 2003; Davies et al. 2006; Sømme et al. 2008), and the Grassy G1 and G2 parasequences (O'Byrne \& Flint 1995). The palaeo-shoreline 
trends in these eastward-prograding parasequences are oriented between NNE/SSW and NNW/SSE (Taylor \& Lovell 1995; O’Byrne \& Flint 1995; Howell \& Flint 2003).

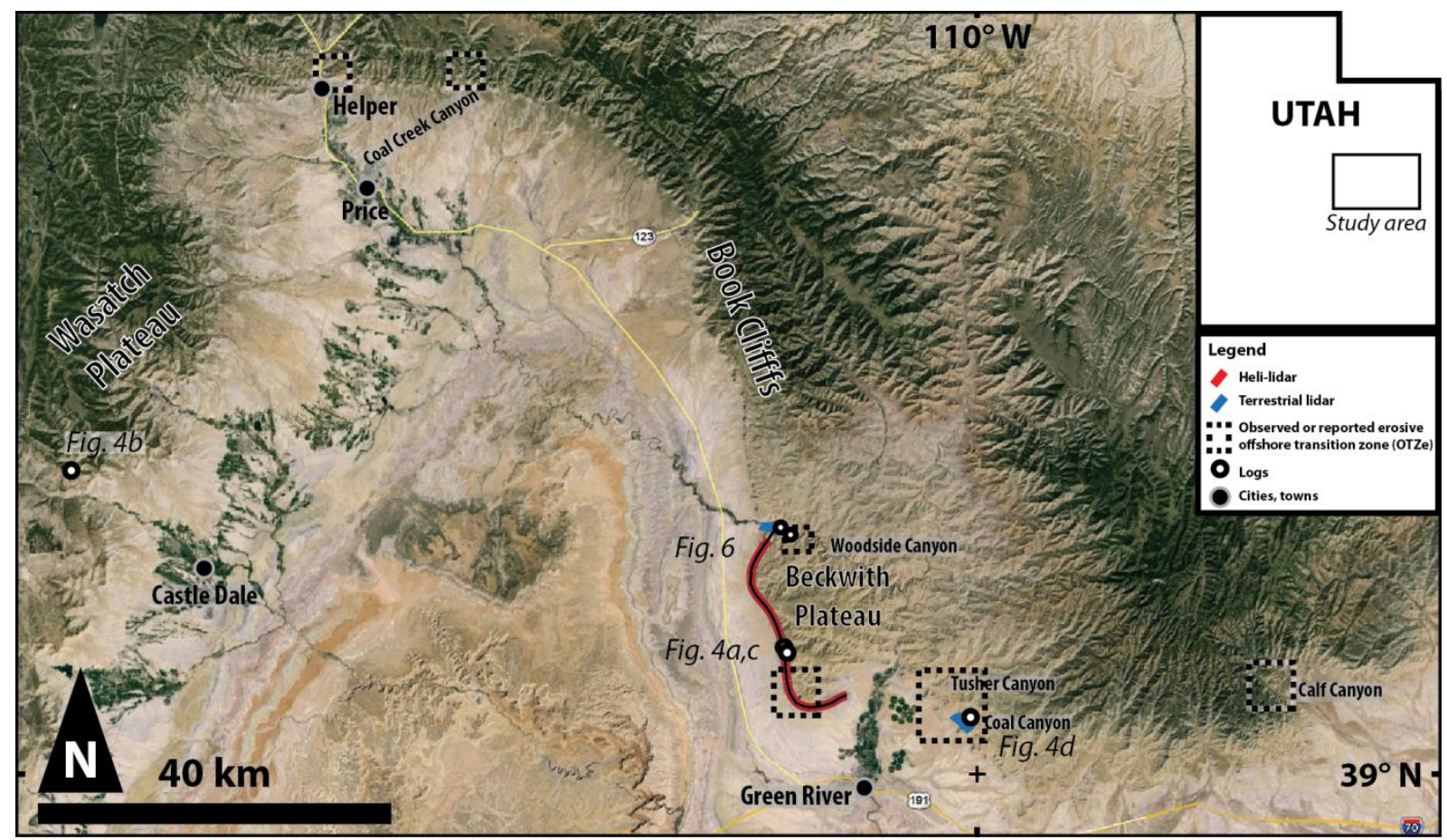

Fig. 1. Map of the study area showing location of logs and virtual outcrops used in this study. Reported and observed occurrences of erosive offshore transition (OTZe) are also shown. The Book Cliffs occur as an escarpment visible in this map from Calf Canyon to west of Castle Dale. Image data are (CGoogle 2013.

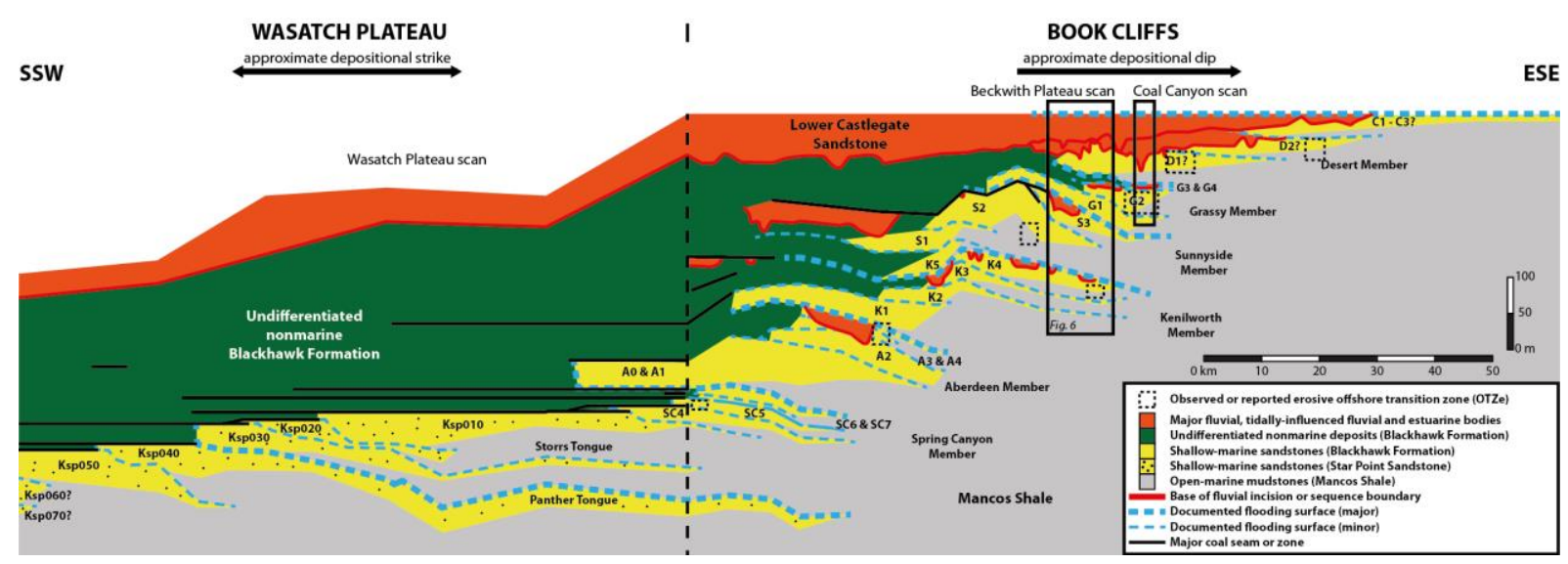

Fig. 2. Stratigraphy and parasequence architecture of the Star Point Sandstone, Blackhawk Formation and Lower Castlegate Sandstone in the Wasatch Plateau and Book Cliffs. Modified from Hampson et al. (2012). Solid black boxes show the stratigraphic intervals covered by the virtual outcrops. Stippled black boxes indicate areas where erosive offshore transition deposits have been reported and observed. 


\section{Dataset and methods}

The dataset used in this study consists of three photorealistic virtual outcrops (Figs. 1-3) and a set of sedimentary logs acquired in the field (Fig. 4). The main dataset consists of a composite of two virtual outcrops, a larger one generated from oblique helicopter-mounted lidar scanning (Buckley et al. 2008a; Rittersbacher et al. 2014) along the face of the Book Cliffs in the Beckwith Plateau (Figs. 1, 2) and a smaller virtual outcrop acquired using terrestrial lidar scanning (Bellian et al. 2005; Pringle et al. 2006, Buckley et al. 2008b) in Woodside Canyon (Fig. 1). A secondary dataset has been used to constrain geometries of erosive offshore transition deposits, and was acquired in Coal Canyon (Figs. 1,2 ) to the east of the main study area using terrestrial lidar scanning.

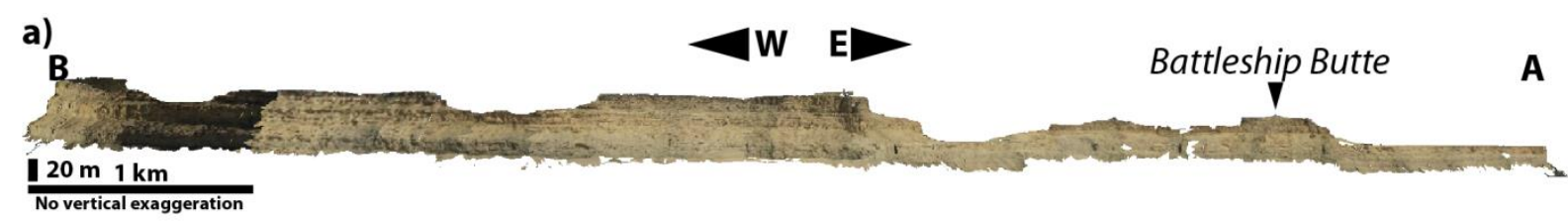

b)

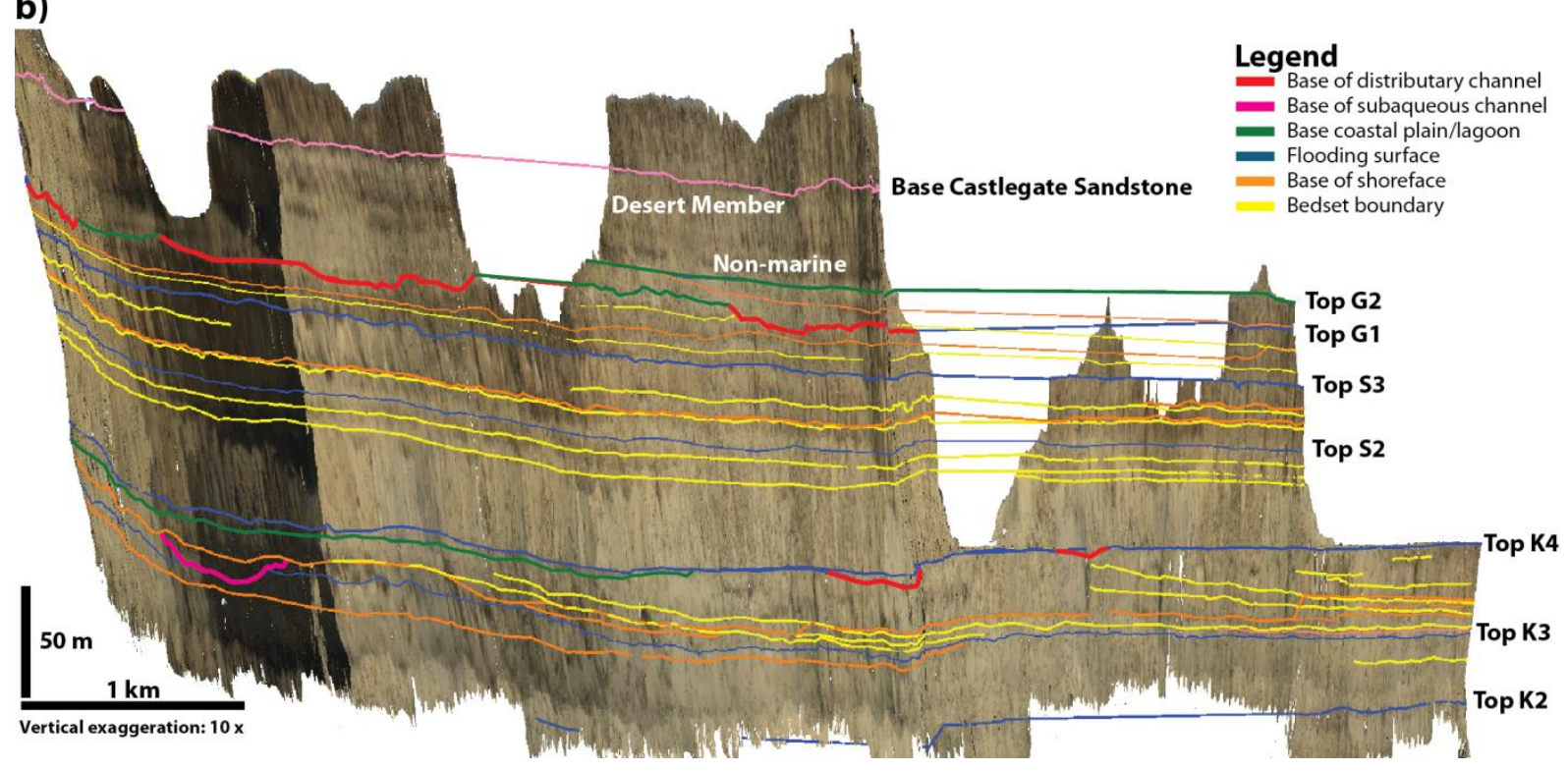

Fig. 3. Uninterpreted (a) and interpreted and $\times 10$ vertically exaggerated (b) outcrop model from the south face of the Beckwith Plateau, facing the town of Green River. Basinwards is towards the east (the right of the figure). This figure corresponds to the section A-B in Figure 6. Note especially the seawards-dipping bedset boundaries in the Kenilworth $K 4$ parasequence and the well-constrained distributary channel in the Grassy G1 Parasequence. K2-4, Kenilworth parasequences K2-4; S2-3, Sunnyside parasequences S2-3; G1-2, Grassy parasequences G1-2.

The helicopter-derived dataset was acquired using the Helimap System (Vallet \& Skaloud, 2004; Buckley et al. 2008a), and the terrestrial lidar models were acquired with a Riegl Z420i laser scanner with a mounted Nikon D200 digital camera (Buckley et al. 2010). The heli-lidar scan covers the entire western and southern faces of the Beckwith Plateau, except for the northernmost $2 \mathrm{~km}$ in Woodside Canyon (Fig. 1). The second model, acquired with the terrestrial scanner, samples the northernmost $1.2 \mathrm{~km}$ of the same cliff face, leaving an $800 \mathrm{~m}$ wide gap between the two scans. The final virtual outcrop model is $27 \mathrm{~km}$ long and roughly horseshoe-shaped (Fig 1), with the southernmost part oriented approximately down depositional dip in relation to the exposed shoreline systems (Figs. 2, $3)$; the middle part oriented approximately along depositional strike, and the northernmost part 
oriented oblique to depositional dip. The third terrestrial lidar model from Coal Canyon (Fig 1) was used to extract bed geometries in erosive offshore transition deposits in the Grassy 2 parasequence (Fig. 2).

The dataset is supported by a set of five measured sections with a total length of $279 \mathrm{~m}$, recording lithology, sedimentary textures and sedimentary structures (Fig. 4). The scanned cliffs are predominantly vertical and effectively inaccessible. Some of the logs have therefore been acquired behind the scanned cliffs and projected onto the virtual outcrop. The expression of facies associations in logs and outcrop models generally show an excellent correspondence to each other (Figs. 4, 5).

Fig. 4 (next page). Measured sections showing characteristic features of the studied deposits. (a) Composite log of the Kenilworth K4 shoreface and overlying lagoonal deposits. The lagoonal part of the log is logged on the scanned outcrop in the Beckwith Plateau, while the shoreface and offshore transition is measured from an outcrop approximately $1.7 \mathrm{~km}$ SE of the outcrop. (b) Log illustrating the wave-dominated delta-front element, from the KSPO10 parasequence in the Storrs member in Cottonwood Canyon, Wasatch Plateau. (c) Log illustrating a sedimentary succession in the Sunnyside S2 and S3 and the Grassy 1 parasequences. Measured directly behind the scanned outcrop. (d) Grassy G2 parasequence in Coal Canyon, measured directly on the scanned outcrop. (e) Legend. 
a)

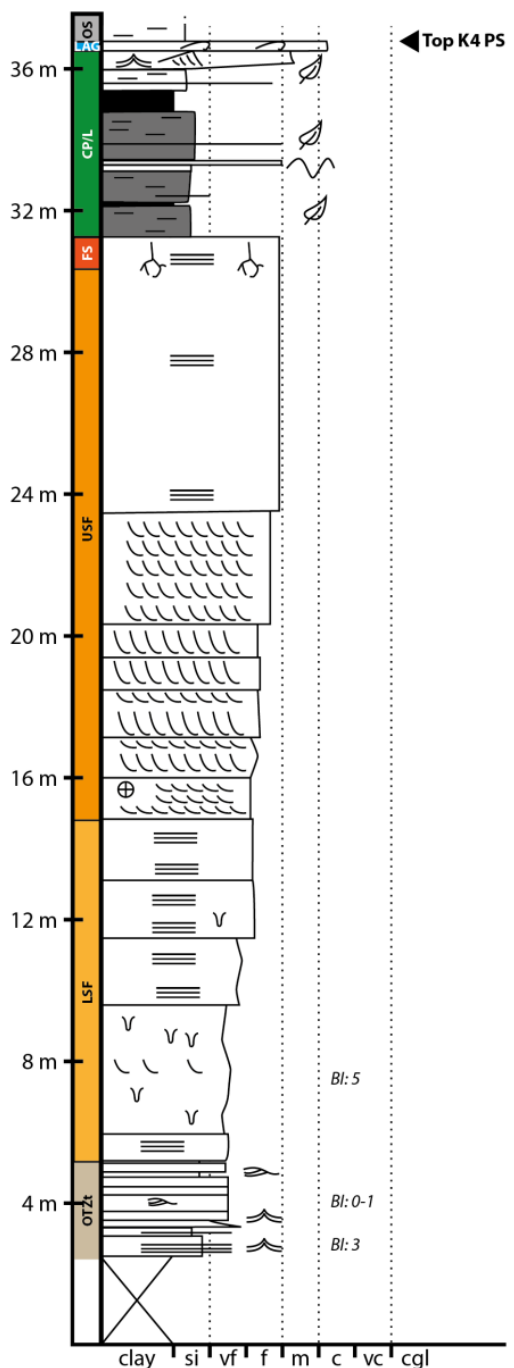

b)

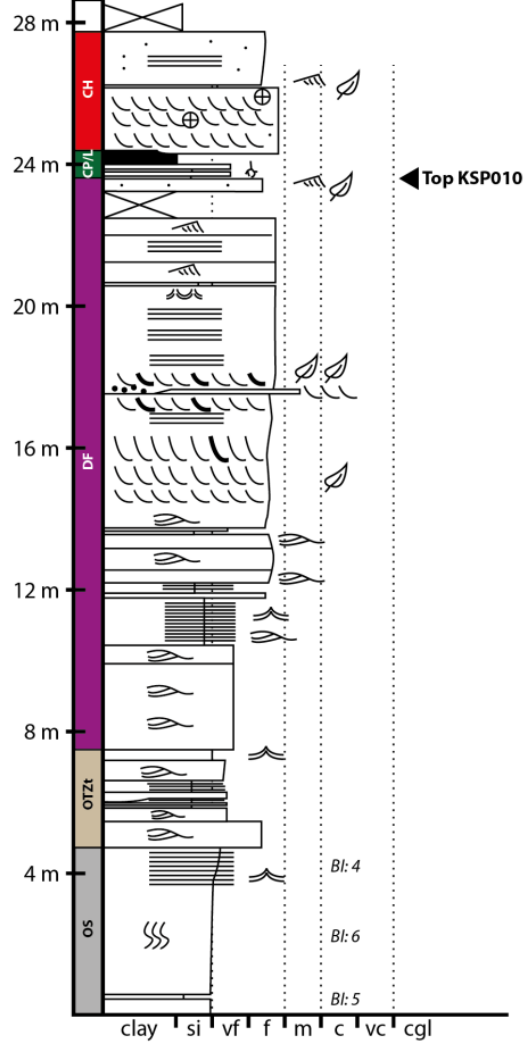

c)

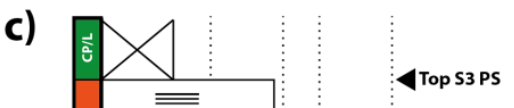

d)

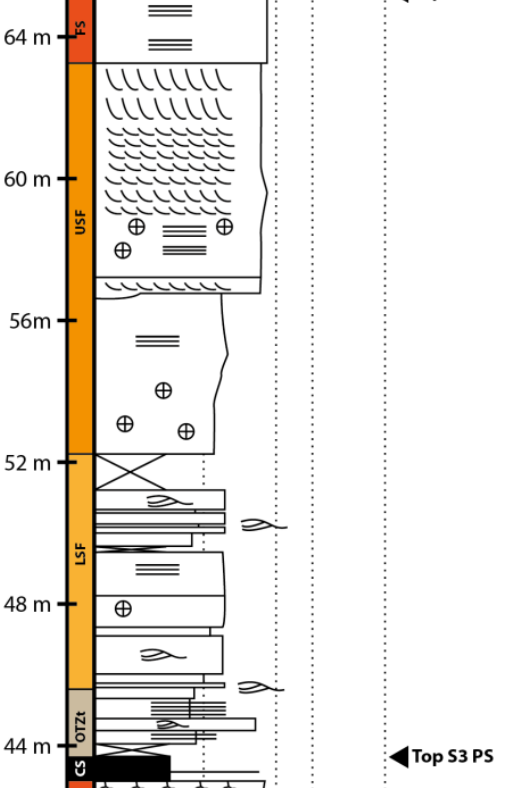

in

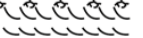

illilll

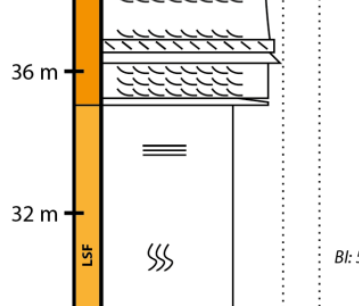

$28 \mathrm{~m}-$

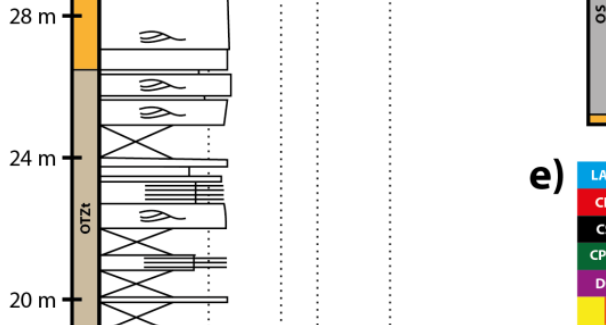

Top S2 PS

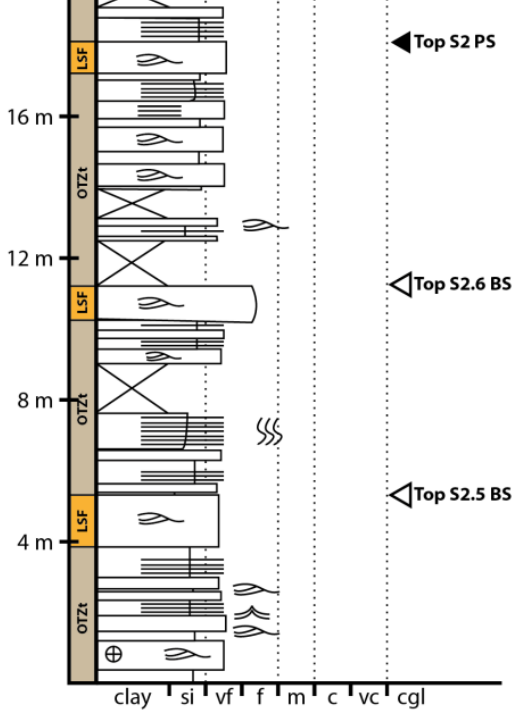

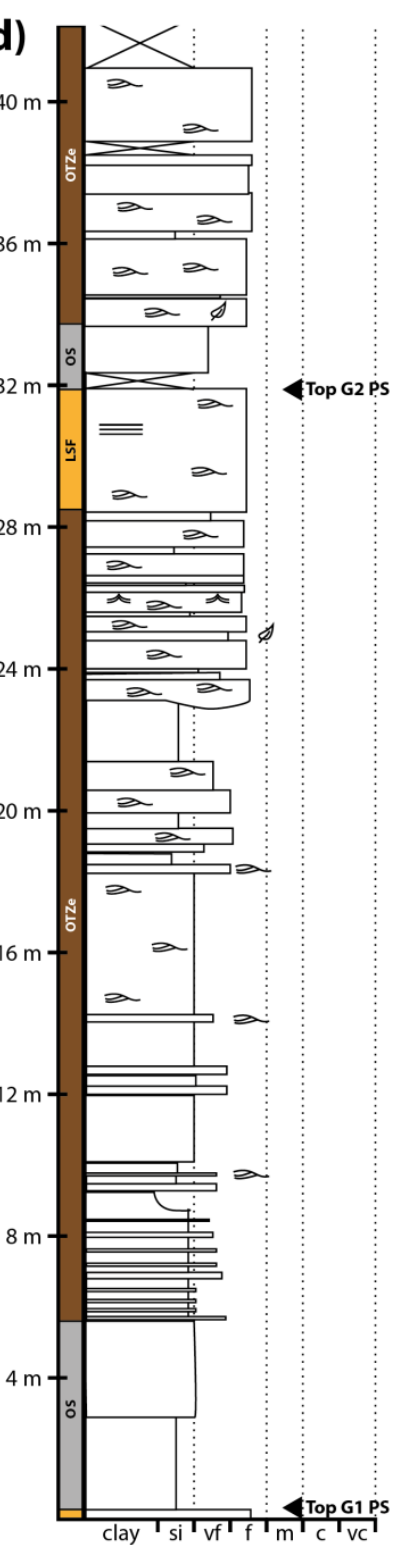

e) LAG Transgressive lag

Distributary channe

Coal swamp

Coastal plain/lagoon

Wave-dominated delta front

Shoreface, foreshore

SF USF Shoreface, upper shoreface

ISF Shoreface, lower shoreface

Subaqueous channel

orzt Gradational offshore transition

Offshore shelf

SSS Intense bioturbation

Shell fragments

\&4: Convolute lamination

$\because$ Massive sandstone beds

ㄴ Trough cross-stratification

ㄴ. Planar cross-stratification

III Current ripples

三 Planar-parallel stratification

حummocky cross-stratification

- Wave ripples

C Carbonaceous foreset drapes

$\sim$ Wavy bedding

$\oplus$ Concretions

$\downarrow$ Rootlets

A Plant fragments

.... Mudclasts

$0 \%$ Extraformational clasts

Carbonaceous mudstone

Coal 


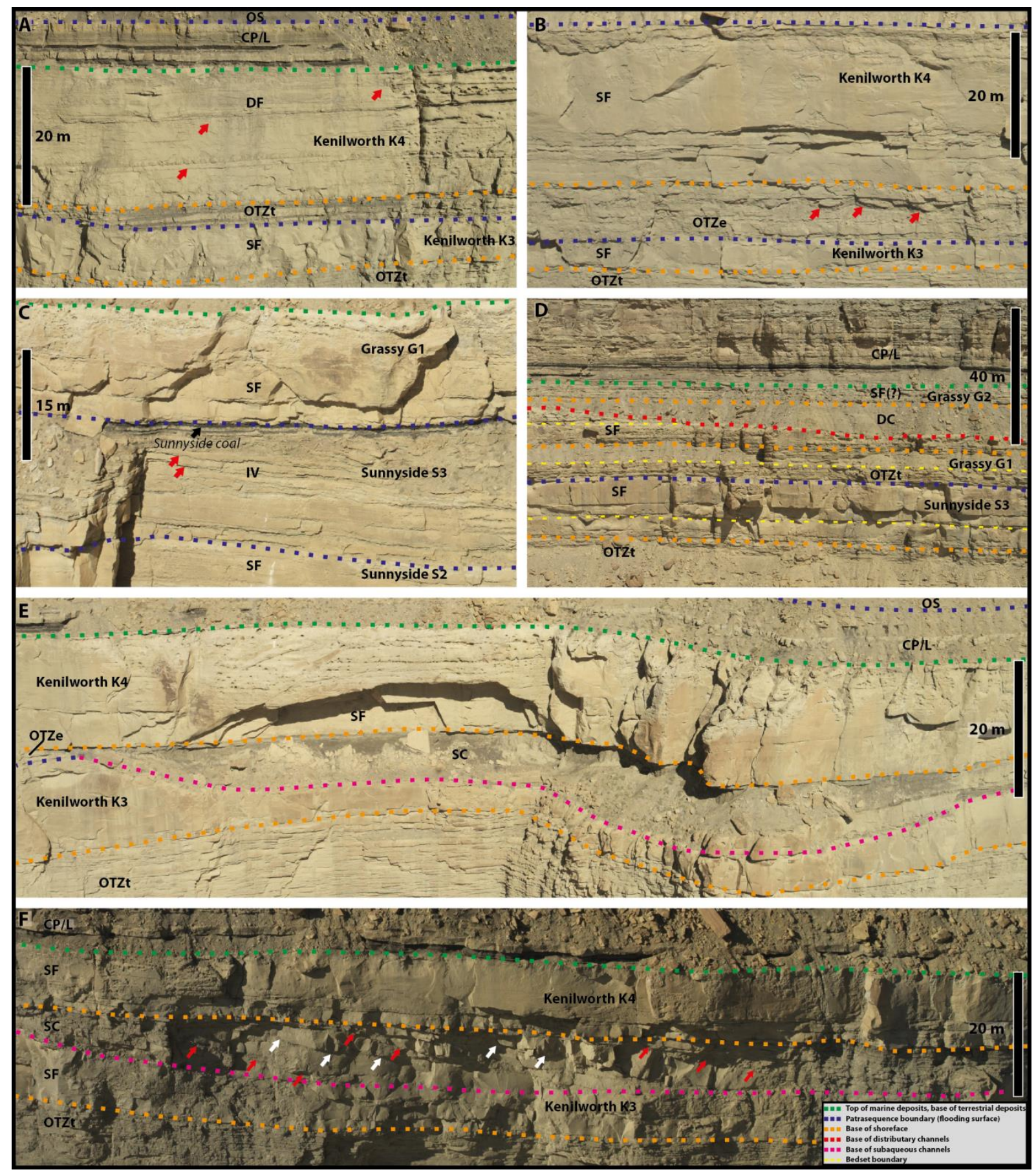

Fig. 5. Examples of depositional elements in the shallow-marine deposits in the Beckwith Plateau. See Figure 6 for location of images. (a) Wavedominated delta front in the Kenilworth $K 4$ parasequence. Characterized by gently dipping clinoforms (arrows). Note also the planar interbedded sandstone-, carbonaceous shale- and coal-beds in the lagoonal deposits $(C P / L)$ on top of the shoreface. (b) Shoreface deposit in the Kenilworth $K 4$ parasequence, underlain by erosive offshore transition-zone deposits (OTZe). Note the approximately $3 \mathrm{~m}$-wide, $1 \mathrm{~m}$-deep gutter casts (arrows). (c) Shoreface of the Grassy G1 parasequence, overlying the Sunnyside coal (black arrow) and the Sunnyside incised valley. (d) Near landwards pinch-out of Grassy 2 parasequence. The shoreface of the Grassy 2 contains abundant clinoforms. Note also the distributary channel in the Grassy 1, eroding the bedset boundary. (e) Mudstone-filled subaqueous channel (SC) eroding into the top of the Kenilworth $\mathrm{K} 3$ 
parasequence. (f) Subaqueous channel in the Kenilworth K4 parasequence. Probable lateral accretion surfaces are highlighted by filled and unfilled arrows.

\section{Lidar acquisition and processing}

Acquisition, processing and visualization of terrestrial (Bellian et al. 2005; Pringle et al. 2006; Enge et al. 2007; Buckley et al. 2008b) and helicopter-derived (Buckley et al. 2008a; Rittersbacher et al. 2013) lidar data is described in detail by previous authors, and only a short summary of the method is presented here. The position of the scanner is recorded using Global Navigation Satellite System (GNSS) measurements, and in the case of the heli-lidar by the use of a complimentary inertial navigation system. A laser-beam is emitted several thousand times a second, and the time-of-flight for this beam is recorded to obtain a distance measurement. The xyz-position of each return on the outcrop surface is calculated using the distance, the direction of the laser beam and the position of the scanner itself. Thus, a point cloud describing the surface of the outcrop is acquired. Digital photographs of the outcrop are acquired simultaneously, and the orientation of the camera is calibrated relative to the laser scanner. For the terrestrial lidar, multiple scans are collected and merged to minimize holes in the dataset, while for the heli-lidar, multiple scan strips are used to cover the vertical extent of the outcrops. Post-processing of the GNSS and inertial data allows the point cloud to be generated from the moving helicopter platform.

In order to create virtual outcrop models from the acquired raw data, the point cloud was filtered to remove erroneous measurements and ensure a near-uniform point distribution. The point-cloud was then triangulated to create a 3D mesh describing the outcrop surface. Finally, the acquired images were textured onto the surface of the 3D model, resulting in a photorealistic virtual outcrop model (Fig. 3). The final outcrop model was visualized and interpreted using in-house software.

Point spacing in the virtual outcrop models for the heli-lidar dataset is c. $0.3 \mathrm{~m}$ for the heli-lidar dataset and c. $0.1 \mathrm{~m}$ for the ground based datasets. The mean pixel resolution of the photos used in the heli- and terrestrial lidar models is 7 and $2 \mathrm{~cm}$ respectively.

\section{Lidar interpretation}

Interpretation of the virtual outcrop models consisted of the following steps: (1) mapping of the key stratigraphic boundaries (flooding surfaces) to provide a stratigraphic framework and then interpretation of the different architectural elements based on weathering characteristics of the cliff faces (Fig. 5), which were calibrated to the logged sections (Fig. 4). (2) Importing lines defining architectural elements to reservoir modeling software to generate surfaces and isopach maps of each element. (3) Measuring the thickness of each element at $200 \mathrm{~m}$ intervals along the outcrop and importing these measurements to spreadsheet software. (4) Plotting of the thickness variations of each element. In order to plot three-dimensional thickness variations on a plane, the flooding surface on top of the Kenilworth 4 parasequence was selected as a datum, as it resulted in the least distortion of the other boundaries. A surface with the least possible topographic variation (i.e. flattest) should be chosen as a datum, because a datum surface will superimpose its own topography onto all other layers after flattening (Bhattacharya 2011). Geometries in the offshore transition zone were investigated by tracing bed boundaries in the lidar data, and subsequently measuring the length and thickness of beds. 
The largest source of potential errors in this methodology relate to the vertical and lateral irregularities in the cliff sections. These can lead to high-frequency undulations in the plotted facies thickness not caused by primary, depositional processes, but purely due to the shape of the outcrop. Examples of these are the short-wavelength, meter-scale undulations on the flooding surface on top of the Sunnyside S2 parasequence.

\section{Results}

\section{Depositional elements}

Because grain size and sedimentary structures cannot be observed directly in the virtual outcrops, the facies scheme used in this study is based on weathering characteristics of the outcrop face observable in the scanned sections. In general, sandstone appears as resistant ledges or massive beige cliff faces. Mudstone appears as grey, slope-forming units in the case of thick beds, and covered or recessed intervals in the case of thinner beds. Coal beds are visible as laterally continuous, black or dark grey layers. Field studies have shown an excellent correspondence between interpreted lithology from virtual outcrops and actual lithology observed in the field (Fig. 4).

The facies scheme used in this study is applied to characterize 11 types of architectural element, which are organized into four sedimentary environments (coastal plain, wave-dominated shorelineshelf, offshore shelf, transgressive lag): coastal plain/lagoon (CP/L), distributary channel (DC), coal swamp (CS), estuarine incised valley fill (IV), shoreface (SF), wave-dominated delta-front (DF), shoreface (SF), tabular offshore transition zone (OTZt), erosive offshore transition zone (OTZe), subaqueous channel (SC), offshore shelf (OS) and transgressive lag (LAG). See Table 1 for more thorough descriptions of the architectural elements.

Because the scanned outcrops mainly occur as vertical cliffs, not all logs are taken directly on the cliffs, but on accessible exposures behind. No accessible examples of the wave-dominated delta-front (DF), subaqueous channels (SC), distributary channels (DC) or erosive offshore transition zone deposits (OTZe) were located in or near the main outcrop in the Beckwith Plateau. Erosive offshore transition zone deposits (OTZe) were therefore logged in Coal Canyon (Figs 1, 4d), on the terrestrial virtual outcrop model from that area. No examples of wave-dominated delta-front (DF) deposits were found in the scanned interval. This element is therefore illustrated with a log acquired in Cottonwood Canyon in the Wasatch Plateau, from the Storrs KSp 010 parasequence (Figs 1, 2, 4b). No accessible occurrences of the subaqueous channels or distributary channels were found within the study area.

This facies scheme is comparable to other facies schemes used in wave-dominated, shallow-marine environments (e.g. Howell \& Flint 2003; Hampson et al. 2011), with one notable exception: It is generally not possible to separate between the facies associations foreshore (FS), upper shoreface (USF) and lower shoreface (LSF) in the lidar data, because these three facies associations consist of mainly amalgamated sandstones. These have therefore been interpreted as one architectural element termed shoreface (SF). Otherwise, there is an excellent correspondence between the architectural elements interpreted from virtual outcrops and logs. 


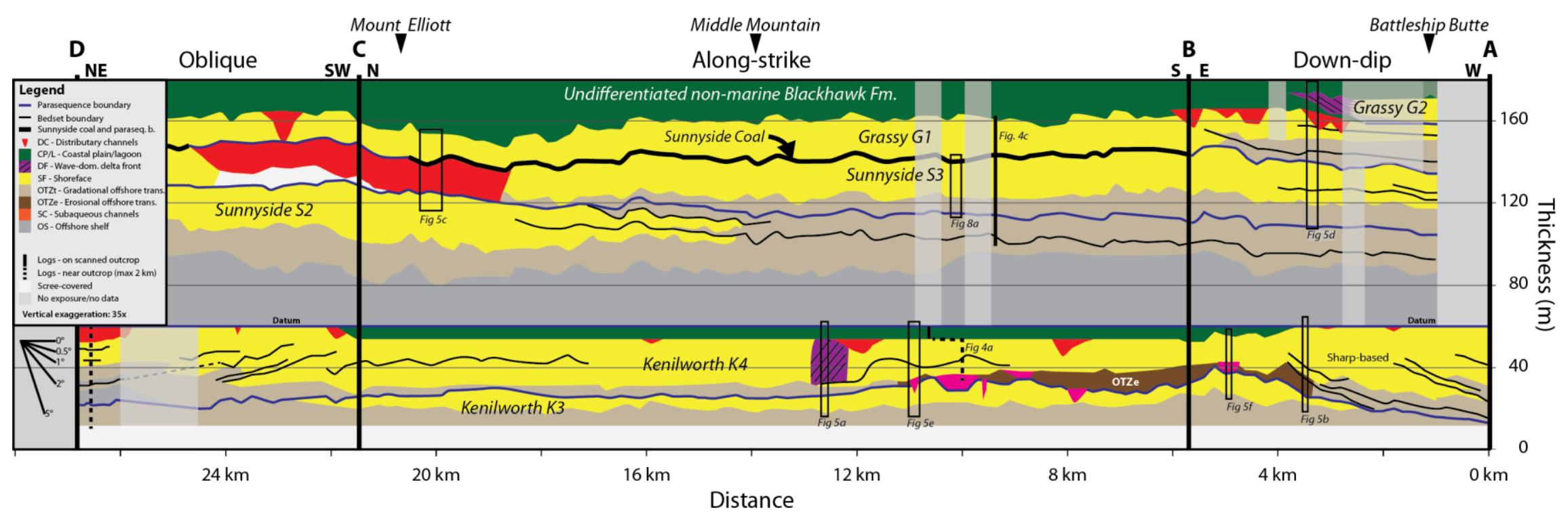

Fig. 6. Panel showing the distribution of architectural elements in the virtual outcrop model from the Beckwith Plateau. The flooding surface on top of the Kenilworth 4 is used as a datum. The high-frequency, metre-scale undulations on the other surfaces are probably mainly related to thickness variations caused by lateral undulations of the cliff face. 


\section{Offshore transition zone (OTZ) deposits}

The Offshore Transition Zone is a heterolithic facies association which underlies the shoreface (SF) and wave-dominated delta elements (DF), and overlies the offshore shelf element (OS) where it is developed (Fig. 6). The boundary between the OTZ and the overlying SF is typically gradational and the OTZ is defined as having more than $5 \%$ siltstone interbeds. The OTZ is characterized by, $5-50 \mathrm{~cm}-$ thick very fine- to fine-grained sandstone beds containing hummocky cross stratification, locally capped by wave-ripples and with variable degrees of bioturbation (bioturbation index: 2-6, sensu Taylor \& Goldring, 1993). The sandstones are interbedded with 1-50 cm thick, bioturbated siltstone beds (Figs 4,7 ). Within the OTZ, the sandstone beds generally thicken upwards, while the number and thickness of siltstone interbeds decrease (Fig. 4). In well-exposed areas, the sandstone beds can be shown to continue into the overlying shoreface (Fig 8 a-b). OTZ deposits are interpreted to form below but near mean storm wave-base, where mudstone beds are deposited from suspension during fair-weather periods, and the hummocky cross-stratified sandstone beds are deposited during occasional strong storms (Elliot 1978, Dott \& Bourgeois 1982). The increase in thickness and abundance of sandstone beds upwards reflects the increased wave-activity as the water shallows as the system progrades.

In the current study, two distinct types of OTZ have been defined, tabular and erosional offshore transition (OTZt and OTZe; Figs. 7 and 8). In the OTZt, beds are generally parallel-sided and separated by continuous siltstone beds (Figs. 7 a,b; 8 a,b). In the OTZe the sandstone beds are irregular with highly erosive bases that cut into and through the underlying siltstone beds (Figs. $7 c, d$; $8 c, d)$. The wavelength of the pinching and swelling of the sandstone beds is 1-5 $\mathrm{m}$, and the degree of amalgamation (sand-on-sand contacts) is commonly more than $50 \%$ (Fig. 8c). The bases of the sandstone beds commonly contain gutter casts up to $50 \mathrm{~cm}$ deep, while the beds contain large scale hummocky cross stratification (Figs 5b; 7d; $8 d$ ), which suggests deposition of the bed, including the fill of the scours, was related to oscillatory wave action (Dott and Bourgeois, 1982; Dumas and Arnott; 2006). It is generally not possible to distinguish between OTZt and OTZe in one-dimensional, vertical sections, such as cores.

Offshore transition zone deposits with tabular beds (OTZt) occur in all the parasequences in the scanned parts of the Beckwith Plateau (Fig. 6). The only place Erosive OTZ (OTZe) occurs in this outcrop is locally in the Kenilworth K4 in the SW part of the outcrop. The offshore transition in the Kenilworth K4 parasequence grades laterally from tabular offshore transition at $3.5 \mathrm{~km}$ (Fig. 6) into erosive offshore transition, and from OTZe into OTZt again at $11 \mathrm{~km}$ (Fig. 6).

OTZe is also observed locally in the Spring Canyon SC5 parasequence near Helper, in the Sunnyside S2 parasequence in Woodside Canyon and in a larger area in the Grassy G2 parasequence from Tusher Canyon to Coal Canyon (Figs 1; 2; 9). Possible controls on the distribution of OTZe and OTZt are discussed later. 

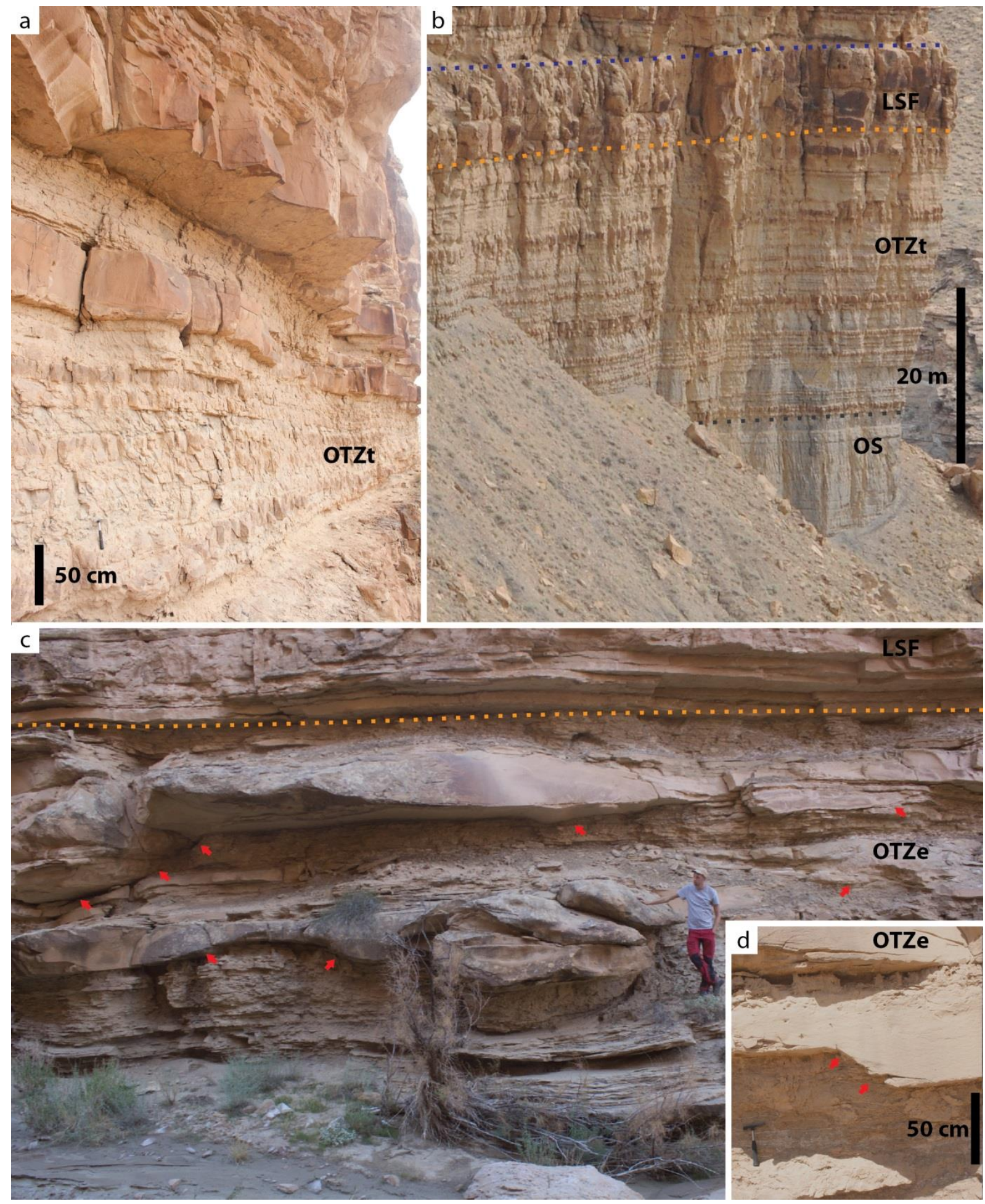

Fig. 7. Images illustrating the difference between tabular and erosive offshore transition-zone deposits. (a) Tabular and parallel-sided, hummocky crossstratified sandstone beds interbedded with tabular siltstone beds, Grassy G2 parasequence in Woodside Canyon. (b) Overview of tabular and continuous interbedded sandstone and siltstone beds of the tabular offshore transition, Grassy G2 parasequence, Woodside Canyon. (c) Erosive, pinching and swelling, hummocky cross-stratified sandstone beds interbedded with siltstone beds in OTZe in the Grassy G2 parasequence, Tusher Canyon. Person for scale is approximately $1.8 \mathrm{~m}$ tall. Small arrows highlight particularly erosive parts. 
(d) Steep-walled gutter cast filled with hummocky cross-stratified sandstone eroding approximately $50 \mathrm{~cm}$ down into a siltstone bed.
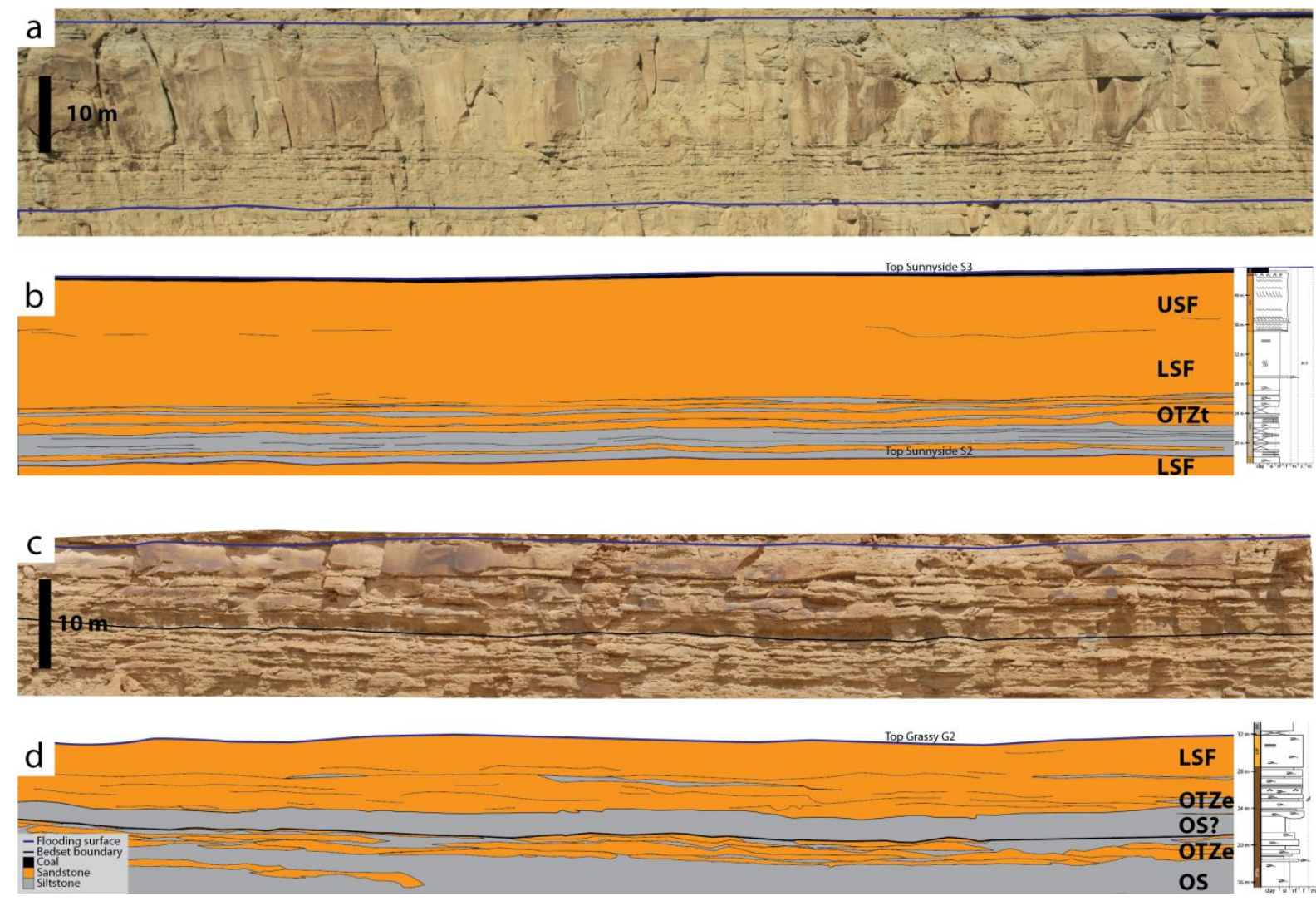

Fig. 8. Images and overlay drawings showing the difference in bed geometries in tabular and erosive offshore transition deposits. (a) Picture and (b) interpretive overlay drawing of tabular offshore transition deposits in the Sunnyside S3 parasequence. (c) Picture and (d) interpretive overlay drawing of erosive offshore transition deposits in the Grassy G2 parasequence in Coal Canyon. Note the tabular geometries and laterally extensive beds in (a) and (b), and the erosive, lenticular geometries in (c) and (d). See Figures 1 and 6 for location.

\section{Subaqueous channels}

Six channelized incisions with concave-up erosion surfaces occur within the OTZe of the Kenilworth K4 parasequence (Figs 5e,f; 6). These incisions are 67-705 $\mathrm{m}$ wide and 4-11 $\mathrm{m}$ deep. The reported widths are apparent and uncorrected, but channels are interpreted to be oriented perpendicular to the shoreline, and are (with one exception) exposed in a shoreline-parallel cut. They frequently cut into the underlying shoreface sandbody of the Kenilworth K3 parasequence, but cannot be part of the Kenilworth K3 because the flanks of channels erode adjacent OTZe deposits of the Kenilworth K4. Muddy, heterolithic and sandy channel fill has been observed, and locally show up to $5^{\circ}$ dipping internal surfaces (Fig. 5f, red and white arrows), interpreted as lateral accretion surfaces. The occurrence of these channel fills within the OTZe of the Kenilworth K4, and below the shoreface (SF), implies that they were deposited subaqueously. The lateral accretion surfaces indicate sustained flow. In the context of a prograding, wave-dominated shoreline fed by multiple deltas developed around fluvial input points (Charvin et al. 2010; Eide et al. 2014), and significant amounts of gravityflow deposits basinwards (Hampson 2010), erosively based channels within OTZ deposits with evidence for sustained flow are likely to be the deposits of subaqueous channels, cut and filled by 
hyperpycnal flows fed from distributary channels up-dip, and feeding shelf turbidite systems downdip (Pattison et al. 2007). These channels could also be interpreted as incised valley fills, but this seems unlikely due to that there are no evidence for this interval being subject to subaerial exposure, and no evidence for contemporaneous lowstand deposits. These channels could also be the deposits of shore-normal channels carved by storm-generated downwelling events (Héquette and Hill 1993; Amos et al. 2003), but this does not explain that the subaqueous channels occur in areas in front of large distributary channels (Fig. 6), as this model would predict that these channels should be located throughout the study area.
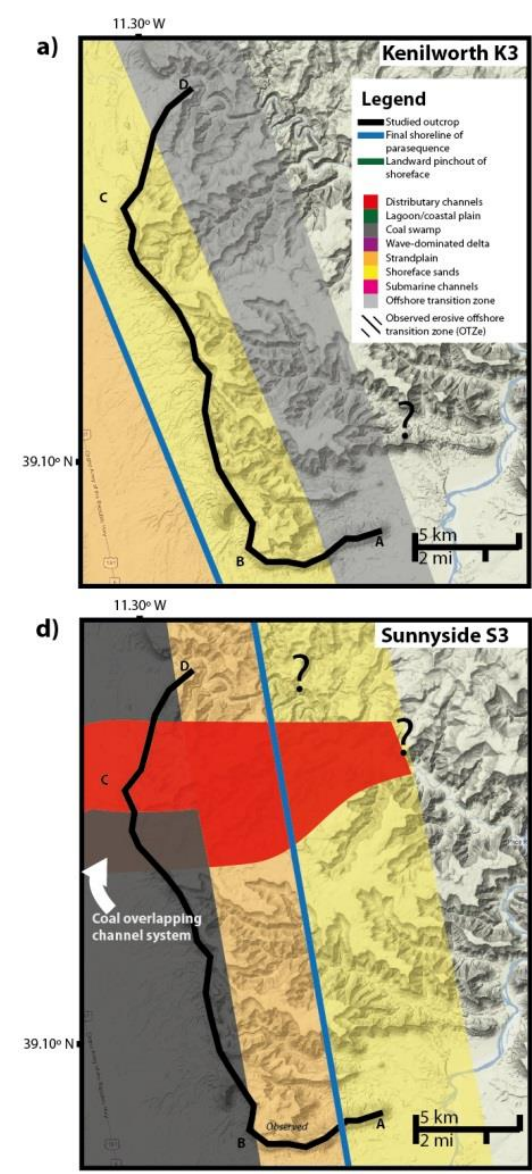
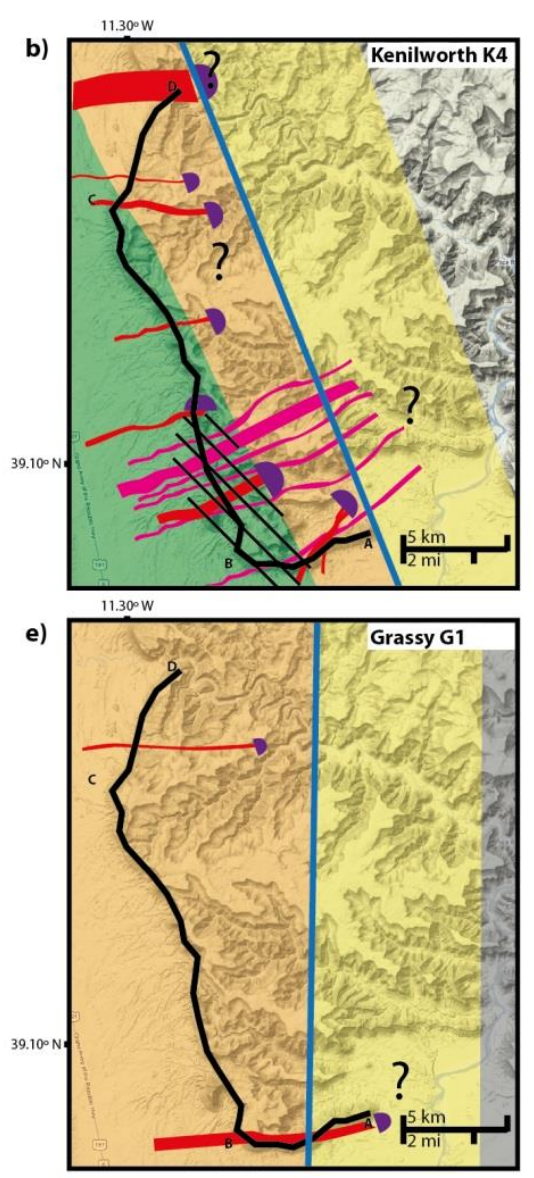
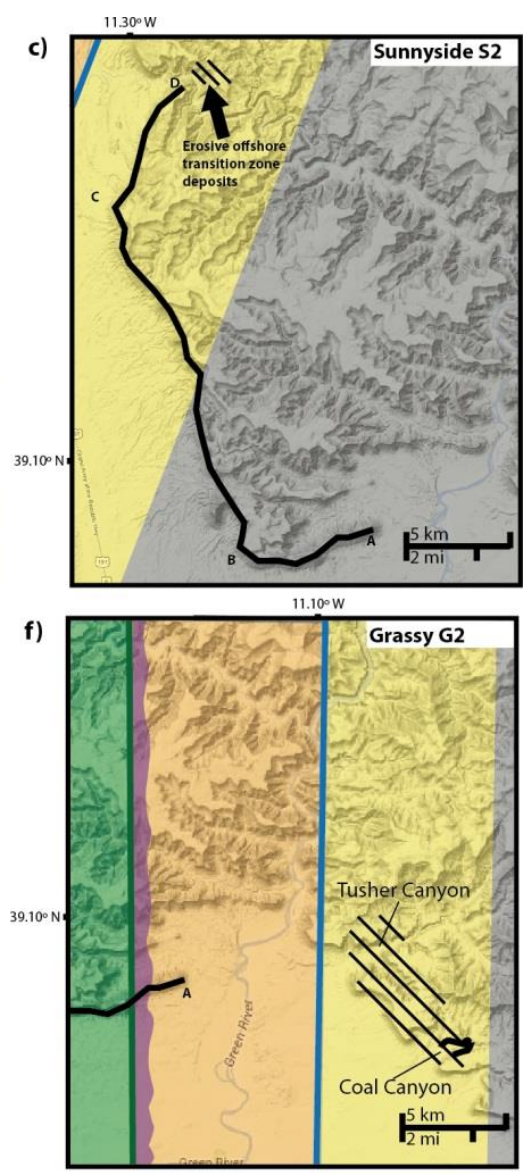

Fig. 9. Palaeogeographical maps of the facies distribution of the studied parasequences just prior to transgression. Facies observations are only made along the outcrop (thick, black line), other geometries are inferred. Final shoreline positions in the Kenilworth K4 from Taylor \& Lovell (1995); Sunnyside S3 from Sømme et al. (2008); and Grassy G1 and G2 from O'Byrne \& Flint (1995). (a) Facies distribution in Kenilworth K3. (b) Facies distribution in the Kenilworth K4 parasequence, which is characterized by an abundance of distributary channels compared to the other parasequences. It is also the only parasequence to contain subaqueous channels within the study area. (c) Map showing the distribution of facies in the Sunnyside 52 parasequence. (d) Facies distribution in the Sunnyside S3 parasequence. The final shoreline in this parasequence is interpreted to lie within the study area. The Sunnyside 3 is overlain by deposits of a regionally extensive coal swamp, and is also incised by a $6 \mathrm{~km}$ wide channelized body. The southern part of this body is overlain by the Sunnyside Coal. (e) Facies 
distribution in the Grassy G1 parasequence. (f) Facies distribution in the Grassy G2 parasequence. Note that the centre of this map is located approximately $10 \mathrm{~km}$ to the SE of the other maps.

\section{Parasequence architecture}

\section{General stacking pattern}

The studied outcrop face in the Beckwith Plateau (Fig. 6) includes six parasequences: Kenilworth K3 and K4 (sensu Taylor \& Lovell 1995); Sunnyside S2 and S3 (Howell \& Flint 2003); and Grassy 1 and 2 (O'Byrne \& Flint 1995). Kenilworth 3 and 4 represent the upper portion of a progradational parasequence set. The flooding surface at the top of Kenilworth 4 marks a much larger transgression than the flooding surfaces bounding the other parasequences (Fig. 2). This is related to a major transgression which led to the deposition of the shallow-marine portions of Kenilworth 5 and Sunnyside 1 parasequences landward of the study area. Within the study area this interval is represented by c. $20-30 \mathrm{~m}$ of offshore deposits. The four parasequences above these offshore deposits also show a progradational stacking pattern.

These simple stacking patterns and the facies model described contain a significant degree of intraparasequence variability in a number of aspects, such as shoreface-element thickness, type of offshore transition deposit, and occurrence of subaqueous channels. This variability can be addressed by comparing the architecture and context of the parasequences.

\section{Kenilworth 3 parasequence}

The Kenilworth 3 is the lowermost exposed parasequence in the study area (Fig. 6). It has a thin shoreface element compared to the other parasequences $(7 \mathrm{~m}$ on average compared to around $20 \mathrm{~m}$ for the other parasequences), which thins towards the east before it abruptly pinches out in the depositional dip section ( $A B$, Fig. 6). It is not overlain by continental deposits and observations in outcrops in Woodside Canyon indicate that within the study area the main sandbody only comprises lower shoreface deposits. The shoreface is underlain by OTZt and lacks submarine channels. There are no bedsets (sensu Van Wagoner et al. 1990; Sømme et al. 2008) within the parasequence.

\section{Interpretation:}

The final shoreline of the Kenilworth K3 is located just west of the study area (Fig. 9a), and the seaward thinning of the shoreface represents the subaqueous slope of the parasequence, which was most likely preserved due to rapid transgression. It is underlain by a thick succession of offshore deposits and prograded into relatively deep water in front of the underlying Kenilworth 2 parasequence.

\section{Kenilworth 4 parasequence}

K4 is the most complex of the parasequences in the Beckwith Plateau (Fig. 6). The shoreface is overlain by up to $6 \mathrm{~m}$ of coastal plain deposits in the eastern part of the outcrop. These coastal plain deposits pinch out towards the west. Within the study area, $\mathrm{K} 4$ is incised into by eight distributary channels, one of which feeds a laterally restricted wave-dominated delta (Figs. 4a, 5a, 6; Eide et al. 2014). The parasequence thickness varies from 15 to $46 \mathrm{~m}$ and the shoreface element thickness varies from 15 to $36 \mathrm{~m}$. The parts of the section with the thickest parasequence do not always correspond to the thickest shoreface deposits. The base of the shoreface element is locally sharp and erosive, but gradational in the majority of the outcrop. Low angle (c. $\left.0.5^{\circ}\right)$ clinoforms can be traced 
through the shoreface into the OTZ, while higher angle clinoforms occur in the wave-dominated delta (c. $2^{\circ}$ ) and also directly above the seaward pinch-out of the Kenilworth K3 parasequence (c. $1^{\circ}$ ) (Fig. 6).

The Kenilworth 4 contains several intra-parasequence, upwards-coarsening bedsets consisting of mainly lower shoreface deposits overlain by basinward-dipping clinoforms that pinch-out basinwards. The bedsets are commonly associated with thicker portions of shoreface, and the most well-developed examples correlate up-dip to the pinch-out of coastal plain deposits $(1,3$ and $24 \mathrm{~km}$ in Fig. 6).

The offshore transition zone deposits in the $\mathrm{K} 4$ consists of three depositional elements: tabular offshore transition zone (OTZt) deposits present in most of the parasequence, and erosive offshore transition zone (OTZe) and subaqueous channels (SC), which are present in the south-eastern part of the study area (Figs. 6 and 9). Six subaqueous channels have been observed in this area.

\section{Interpretation:}

Taylor \& Lovell (1995) interpreted the Kenilworth K4 as a late highstand parasequence overlain by a sequence boundary, and suggested that lowstand deposits lay further basinward at Hatch Mesa. Ainsworth \& Pattison (1994) and Pattison (1995) interpreted it as forced-regressive, attached lowstand. In a detailed study of photo panels from the area, Hampson and Storms (2003) suggested that there was no major sea level fall, but that the shoreline trajectory was gently climbing until it was finally transgressed, with locally sharp-based intervals caused by minor (meter-scale) falls in relative sea-level. The flat to locally ascending shoreline trajectories observed in this study, and the presence of previously undocumented lagoonal deposits in the western side of the section favors an interpretation with an overall rise in sea-level.

Significant thickening of the Kenilworth $\mathrm{K} 4$ parasequence, from $20 \mathrm{~m}$ at $4.5 \mathrm{~km}$ in the virtual outcrop, to $46 \mathrm{~m}$ at $0 \mathrm{~km}$ (Fig. 6), occurs seawards of the pinch-out of the Kenilworth K3 shoreface. This pinchout created a pronounced bathymetric break, where the Kenilworth K4 shoreface prograded from the shallow platform on top of the K3 parasequence, into the deeper water seaward of this platform break.

The K4 shoreface sandbody also thickens in this area, from $18 \mathrm{~m}$ at $4.5 \mathrm{~km}$ to $36 \mathrm{~m}$ at $1 \mathrm{~km}$. The shoreface element in this area contains abundant bedsets, and the pinchout of the lagoonal deposits (Fig. 6) shows that the shoreline trajectory is ascending. The final shoreline of the K4 occurs less than $1 \mathrm{~km}$ west of profile $A B$ (Hampson \& Storms 2003). It is therefore likely that most of the thickening of the shoreface in this area is due to the ascending shoreline trajectory and stacking of bedsets. The fact that the shoreface thins to $25 \mathrm{~m}$ at $0 \mathrm{~km}$ corroborates this hypothesis (Eide et al. 2014).

One of the largest distributary channel deposits (at $12 \mathrm{~km}$ in Fig.6), is associated with wavedominated delta deposits in the parasequence, demonstrating that these bodies are distributary channels rather than incised valleys, as interpreted by Taylor \& Lovell (1995).

The subaqueous channels which cut through the offshore transition zone deposits occur in the same areas as the largest distributary channels in the area (Fig. 9b). Erosive offshore transition zone deposits only occur near the subaqueous channels and near the steeply seaward-dipping pinchout of the K3 parasequence. Possible interpretations for this distribution are discussed later. 


\section{Sunnyside 2 parasequence}

The Kenilworth K5 and Sunnyside S1 parasequence pinch-out further to the west and are not present in the study area (Fig. 2). Thus, the Sunnyside S2 parasequence overlies the Kenilworth K4 parasequence here. In the northern part of the study area, the Sunnyside 2 parasequence contains a $20 \mathrm{~m}$ thick sandy shoreface element overlying c. $40 \mathrm{~m}$ of offshore transition and offshore deposits (Fig 6). At c. $17 \mathrm{~km}$ (Fig. 6), this shoreface splits into three bedsets. There are no distributary channels within the shoreface deposits. The shoreface sandbodies in these tongues pinch-out towards the SE, and the parasequence thins gradually from $65 \mathrm{~m}$ in the north to $45 \mathrm{~m}$ in the southern part of the outcrop. The offshore transition deposits in the study area are tabular in the virtual outcrop model (Fig. 6), but erosive offshore transition deposits are observed locally in the two upper bedsets in Woodside Canyon (Fig. 9).

\section{Interpretation:}

The Sunnyside S2 parasequence prograded into the deep water in front of the K5 and S1 parasequences, which explains its greater thickness. It is mainly composed of lower shoreface and offshore transition deposits in the study area (Fig. 9c; Howell \& Flint 2003; Davies et al. 2006; Sømme et al. 2008), and the final shoreline is believed to have been located several kilometers west of the Beckwith Plateau outcrops (Fig 7; Howell \& Flint 2003). The occurrence of multiple bedsets in the Sunnyside 2 parasequence is attributed to the relatively deep water into which it prograded.

\section{Sunnyside 3 parasequence}

The Sunnyside 3 parasequence is well-exposed in the study-area. The mean shoreface thickness is 18 $\mathrm{m}$, and it starts to thin, develop bedsets and pinch-out in the SE part of the study area (Fig. 6). The parasequence thickens gradually from 20 to $30 \mathrm{~m}$ towards the SE. The shoreface thickness stays almost constant while offshore transition deposits thicken to fill the available accommodation space (Fig. 6). All offshore transition deposits in the S3 are of the tabular type. No distributary channels were observed in SPS3 but it is cut by a major $6 \mathrm{~km}$ wide, up to $22 \mathrm{~m}$ thick incised valley in the northeastern part of the deposit (Figs. 4b; 6; 9d) (Howell \& Flint 2003, Davies et al. 2006).

\section{Interpretation:}

The S3 parasequence prograded in to relatively shallow water above the S2 parasequence, which explains the lack of variation in thickness. The gentle, $10 \mathrm{~m}$ parasequence thickening seaward is probably related to shallow, gently seawards deepening paleobathymetry on top of the Sunnyside S2 parasequence, rather than significant relative sea level rise during deposition, since no landwardthickening backbarrier deposits or overthickened shoreface deposits caused by stacking of bedsets are observed.

\section{Grassy 1 parasequence}

The Grassy parasequence shows a gradual thickening from c. 10 to $20 \mathrm{~m}$ southwards from $17 \mathrm{~km}$ to 6 $\mathrm{km}$ in the virtual outcrop model, and an abrupt thickening at $4.5 \mathrm{~km}$ (Fig 6). The shoreface element thickens correspondingly from $10 \mathrm{~m} 20 \mathrm{~km}$, to $15 \mathrm{~m}$ at $4.5 \mathrm{~km}$, and thins from $4.5 \mathrm{~km}$ to the end of the profile. In the updip portion there are virtually no OTZ deposits present and the shoreface fills the available accommodation. Tabular offshore transition deposits are present seawards of $4.5 \mathrm{~km}$.

The Grassy 1 parasequence contains two distributary channels, one at $23 \mathrm{~km}$ and one at $4 \mathrm{~km}$ in the virtual outcrop (Fig. 6). The distributary channel at $23 \mathrm{~km}$ is covered by scree, so no internal 
architectures can be observed. The southern channel is sub-parallel to the undulating outcrop face, and is exposed in one perpendicular and two near-parallel cuts (Figs 3; 5e; 6). The near-parallel cuts show lateral accretion surfaces, and correlation of the cut banks reveals that the channel was oriented east-west (Fig. 9e).

\section{Interpretation:}

After transgression of the top of the Sunnyside S3 parasequence, the Grassy G1 shoreface prograded into the shallow water platform on top of the preceding parasequence. In the landward portion of the section the water depth was too shallow to deposit a significant thickness of OTZ. As the parasequence prograded into the deeper water seaward of the final S3 shoreline, the sediment supply could not keep up with available accommodation, and bedsets were developed before the parasequence was transgressed. It is possible that this bedset is an initial response to the relative sea-level rise that led to the transgression of the G1 parasequence.

\section{Grassy 2 parasequence}

The Grassy 2 parasequence only occurs in the most paleoseaward $4 \mathrm{~km}$ of the Beckwith Plateau (Fig. 6). The shoreface element pinches out landward into coastal plain deposits, and the most landward 2 $\mathrm{km}$ of the shoreface contain more dipping muddy interbeds than any of the other shoreface elements in the area (Fig. 5e). After a $1.5 \mathrm{~km}$ section without exposure, the Grassy 2 shoreface occurs as a typical shoreface without discontinuous, muddy interbeds, and the shoreface fills the available $12 \mathrm{~m}$ of accommodation space above the Grassy 1 flooding surface. Seaward of the main study area, erosive offshore transition deposits are observed in a more than $6 \mathrm{~km}$ wide and $2 \mathrm{~km}$ long (along depositional strike and dip, respectively) area near Tusher Canyon and Coal Canyon (Figs 7c; 8c; 9f)

\section{Interpretation:}

The Grassy 2 parasequence was deposited immediately after transgression of the Grassy 1 parasequence. The landward pinch-out is believed to mark the most landward position of the shoreline. This indicates a relative sea-level rise of $9 \mathrm{~m}$ from the interpreted final shoreline position of the Grassy 1 to the Grassy 2 parasequences. The abundant recessive breaks in the G2 parasequence in the most landward position most likely represents discontinuous mudstone beds of interpreted fluvial origin present in the shallow-marine sandstones. These are preserved because the sandbody is not as reworked by waves as more seawards deposits, possibly because wave energy was lower in the shallow water in front of this parasequence because of frictional damping by the shallow sea-floor, resulting in larger fluvial influence relative to waves and more river-dominated deposits (Ainsworth et al. 2011). When the G2 prograded into deeper water, wave-energy increased relative to other processes, and it quickly developed into a more regular shoreface (Figs 6 ; 9f).

\section{Modelling of effective vertical permeability for OTZ deposits}

Geocellular reservoir models were built to determine the impact of the tabular versus erosive offshore transition zone deposits on reservoir performance and fluid flow. The goal of the modelling was to compare the effective vertical and horizontal permeability of a representative volume of the two types of OTZ. The models were $1000 \times 1000 \times 20$ m (Fig. 10a), which was large enough to be repetitive and considered to be representative. Cells within the models were $10 \times 10 \mathrm{~m}$ in horizontal extent and $0.2 \mathrm{~m}$ thick, in order to capture detail of the thin mudstone beds within the OT. Each model contained one million cells. The models were populated with facies using an object-based 
modelling approach (e.g. Holden et al. 1998), in which elliptical shale objects were placed within a sandstone background.
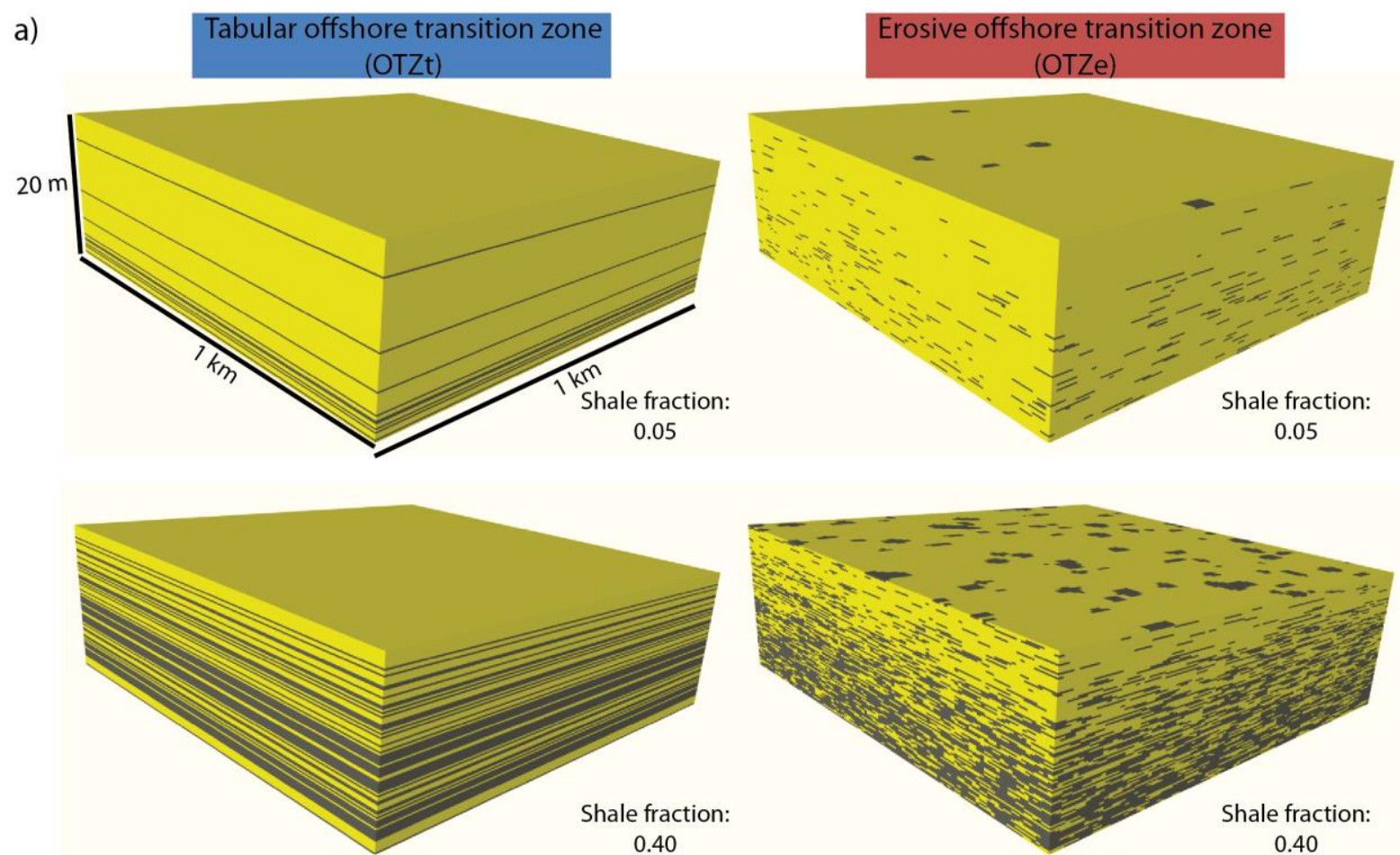

b)

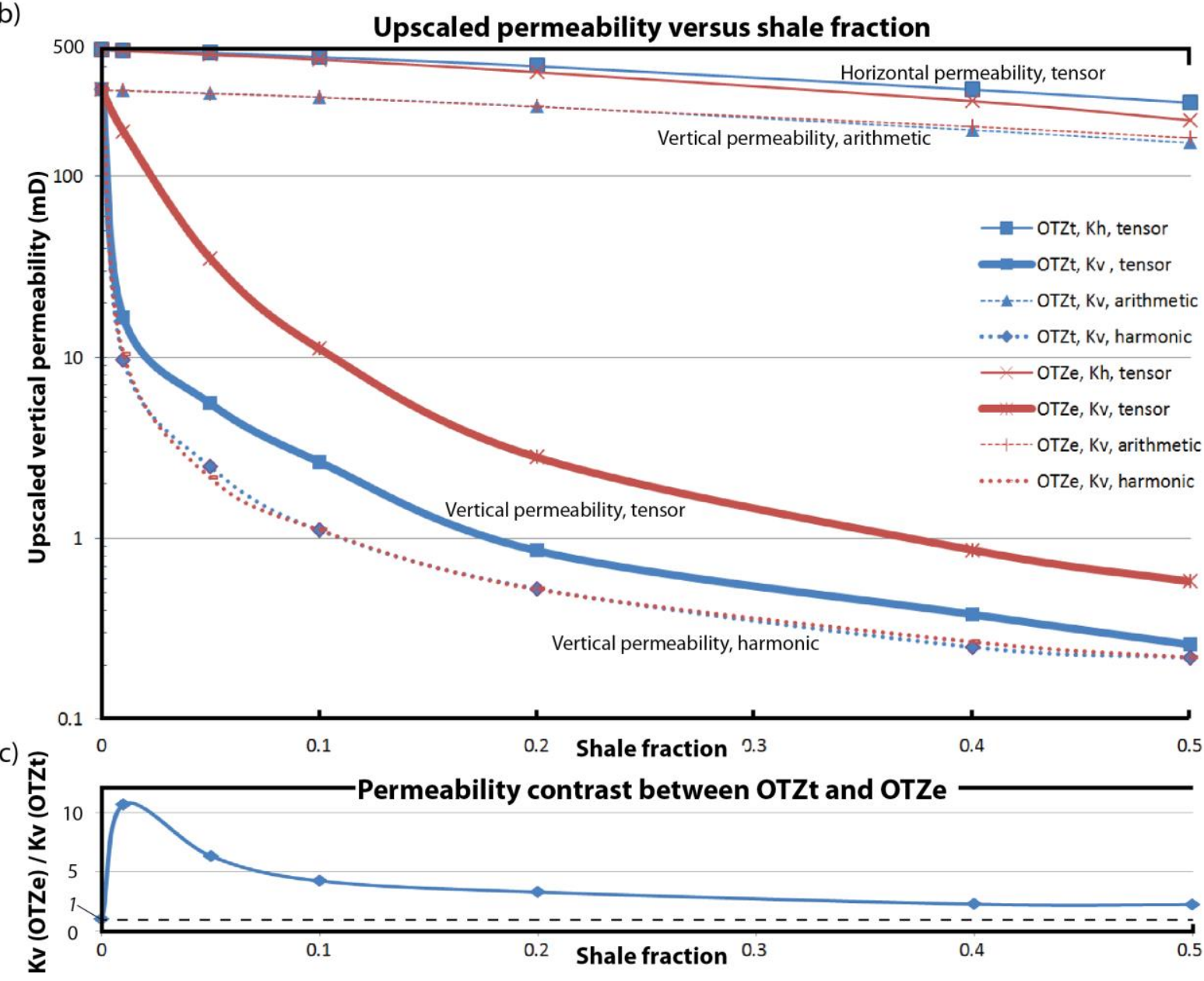


Fig. 10 (previous page). Reservoir models and modelling results. (a) Examples of four of the 12 constructed reservoir models of tabular and erosive offshore transition-zone deposits (left and right, respectively) shown with shale fractions of 0.05 and 0.4 (upper and lower, respectively). (b) Upscaled permeability $v$. shale fraction for the different models. Red lines are for OTZe; blue lines for OTZt. Solid lines show tensor upscaling, and stippled lines show less accurate averaging upscaling methods for comparison. (c) Plot showing the ratio between vertical permeability in OTZt and OTZe deposits.

12 models were constructed, where the proportion of shale varied from 0.01 to 0.5 . Shale objects were populated into the model using a linear vertical trend with $5 \%$ at the top and $80 \%$ at the base. In the OTZt model the shale objects were modelled as ellipses with a mean length of $5 \mathrm{~km}$ and a distribution truncated to 3 and $10 \mathrm{~km}$. This provided sheets which covered the entire volume of the model (Fig. 10a). This is based on observations and measurements in the virtual outcrops, where individual beds in the OTZt could be traced until they encountered covered intervals or data quality artefacts, for at least 0.5 kilometers. Only a few instances of OTZt bed terminations are observed in the entire, $27 \mathrm{~km}$ long virtual outcrop, and it is therefore assumed that sandstone beds in the OTZt are continuous for kilometers (Figs. 8a-b).

Shale objects in the OTZe model were modelled as ellipses with a mean length of $60 \mathrm{~m}$ and a standard deviation of $10 \mathrm{~m}$. This was based on measurements from the virtual outcrop in the Grassy G2 (Figs. 8b-c), and resulted in highly discontinuous shale beds and a high degree of vertical communication between the sandstone beds (Fig 10a), similar to that observed in outcrop. In both cases shale bed thickness was set to $0.1 \mathrm{~m}$, which ensured that all of the shales in the models were a single cell thick.

Petrophysical properties were assigned deterministically by facies, with values chosen to be typical for analogous deposits in the North Sea (e.g. Manzocchi et al., 2008). Sandstone was given a horizontal permeability $\left(K_{h}\right)$ of 500 millidarcy and a vertical permeability $\left(K_{v}\right)$ of 300 millidarcy. Shale was assigned $a K_{v}$ and $K_{h}$ of 0.1 millidarcy. It is obvious that the effective permeability will decrease with decreasing shale permeability, but investigation of this is outside the scope of this work.

Each of the two models, which consisted of one million cells, was upscaled to a single cell using the diagonal tensor upscaling (Wen \& Gómez-Hernandez 1996) method in a commercial modelling package. This is a suitable method for rescaling of heterogeneous models, because it involves flowsimulation. Results are presented in Figure 10b. These show that the effective horizontal permeability is very similar in the two classes of models Plots of effecive vertical permeability shows a contrast of near 10x between OTZe and OTSt at low shale fractions near 0.01 , and declines rapidly to $4 x$ at shale fractions of 0.1 , and more gradually towards $2 x$ at a shale fraction of 0.5 (Fig. 10c). This shows that effective vertical permeability is impaired to a greater degree by the presence of continuous shales in the OTZt model, while the discontinuous mudstone beds in the OTZe model allow for good vertical communication. The differences in vertical permeability highlight how important it may be to distinguish these two types of OTZ in a reservoir setting. 


\section{Discussion}

\section{Conditions favoring the formation of OTZe}

Given the significant differences in vertical permeability between the OTZe and OTZt, it is desirable to predict the distribution of these architectural elements in subsurface reservoirs. The key to predicting this is to understand the processes and depositional conditions that favor the formation of one type of OTZ deposit over the other.

The offshore transition zone deposits in the Kenilworth K4 parasequence grades from OTZt to OTZe within the acquired virtual outcrop. Some architectural relations are unique to the area where OTZe developed (3.5-11 km in Fig. 6), suggesting that a combination of these conditions caused the OTZ to be erosive here:

(1) The K4 parasequence is at its thinnest where OTZe is developed, demonstrating that the parasequence prograded in shallow water. (2) A wave-dominated delta and two large distributary channels occur in the area near the OTZe deposits (Figs 6; 9b). This indicates that this area received a significant sediment supply by fluvial processes, in contrast to the nearby strandplains which mainly received sediment through longshore drift (c.f. Bhattacharya \& Giosan, 2003). (3) The shoreface of the Kenilworth K4 has several sharp-based intervals in the southern part of the study area (Pattison 1995; Hampson \& Storms, 2003). These are interpreted to be caused by low-amplitude (metre scale), short duration relative sea level falls. (4) Several subaqueous channels are developed in the Kenilworth K4 parasequence (Figs 6; 9), which only occur within the OTZe interval. (5) The thickness of the Kenilworth K4 parasequence increases abruptly seaward in this area. This is caused by the pinch-out of the shoreface sandbody of the underlying Kenilworth K3 parasequence (Fig. 6).

One possible model is that progradation of the parasequence in shallow water on top of the preceding parasequence causes the OTZ to be erosive. However, shallow bathymetry alone is not sufficient to explain the presence of OTZe deposits, because many other parasequences prograde in shallow water but exhibit OTZt deposits (e.g. northern part of K4, G1 and S3, Fig. 6).

A second model is that proximity to a fluvial input-point promotes the formation of OTZe, possibly due to scour by hyperpycnal currents. However, OTZe deposits are not reported in areas near deltas in other parasequences, such as the Aberdeen 1 (Charvin et al. 2010) or Storrs KSP010 parasequences (Eide et al. 2014).

Falling relative-sea level and forced regression has been proposed as a mechanism to generate gutter casts and facies associations similar to the OTZe deposits described in this paper (Plint, 1991; Hadley \& Elliott 1993), and a third model is that OTZe depostis are generated during forced regression. It does not seem likely that forced regressions have had a major control on the development of OTZe in the studied deposits, as there are sharp-based intervals in the Kenilworth K4 which show no OTZe (most notably where a bedset is truncated at $3.25 \mathrm{~km}$, Fig. 6, and because no intervals of sharp-based shoreface have been observed from the areas with OTZe deposits in the Sunnyside S2 and Grassy G2 parasequences.

\section{Proposed model}

Subaqueous channels (SC) in the Kenilworth K4 are developed exclusively within OTZe deposits (Fig. 6 ), suggesting that the elements formed under the same conditions. Channels encased within marine 
shales and lower shoreface deposits have also been described from the Grassy G2 parasequence, where OTZe deposits are observed (Figs 1, 2, 8). O'Byrne and Flint (1995) interpreted these channels as incised valleys, but in light of the abundant subaqueous channels (Pattison 2005a, b; Pattison et al. 2007) and basinal gravity flow deposits (Hampson, 2010) recently described within the basin, the channels in the Grassy G2 are more likely to represent subaqueous channels. These channels are interpreted to be turbidite-filled subaqueous channels linking river mouths to prodelta turbidite lobes, cut by river-fed hyperpycnal currents (Pattison, 2005a, b; Pattison et al. 2007). Several authors have described localized erosion near turbidite channels (Elliott 2000; Higgs 2004) and proximal turbidites (Amos et al. 2003). Erosion due to bypassing turbidites is therefore a reasonable mechanism that may explain the presence of erosive offshore transition zone deposits. The OTZe and subaqueous channels form in discrete areas in the studied deposits, and this fits well with the proposed models of relatively widely spaced deltas separated by strandplains in the Blackhawk Formation (Hampson and Howell, 2005; Sømme et al., 2008; Eide et al., 2014). The presence of OTZt deposits in the most paleoseaward parts of the Kenilworth $\mathrm{K} 4$ parasequence (3.5-0 km in Fig. 6) is possibly related to avulsion of the delta system away from this location (Fig. 11d).

a)
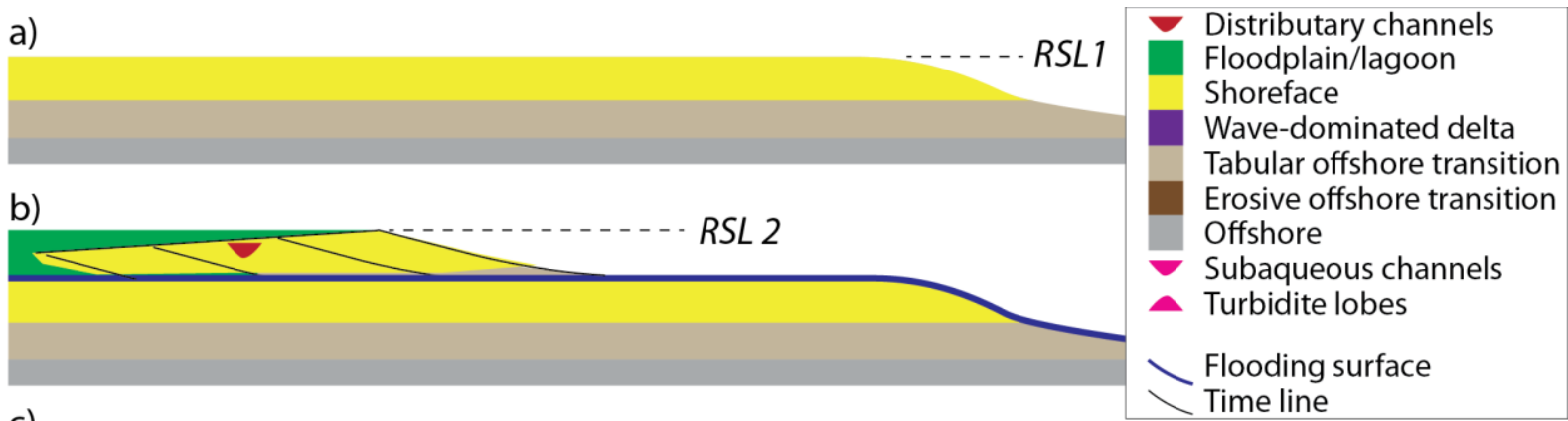

c)

RSL 3
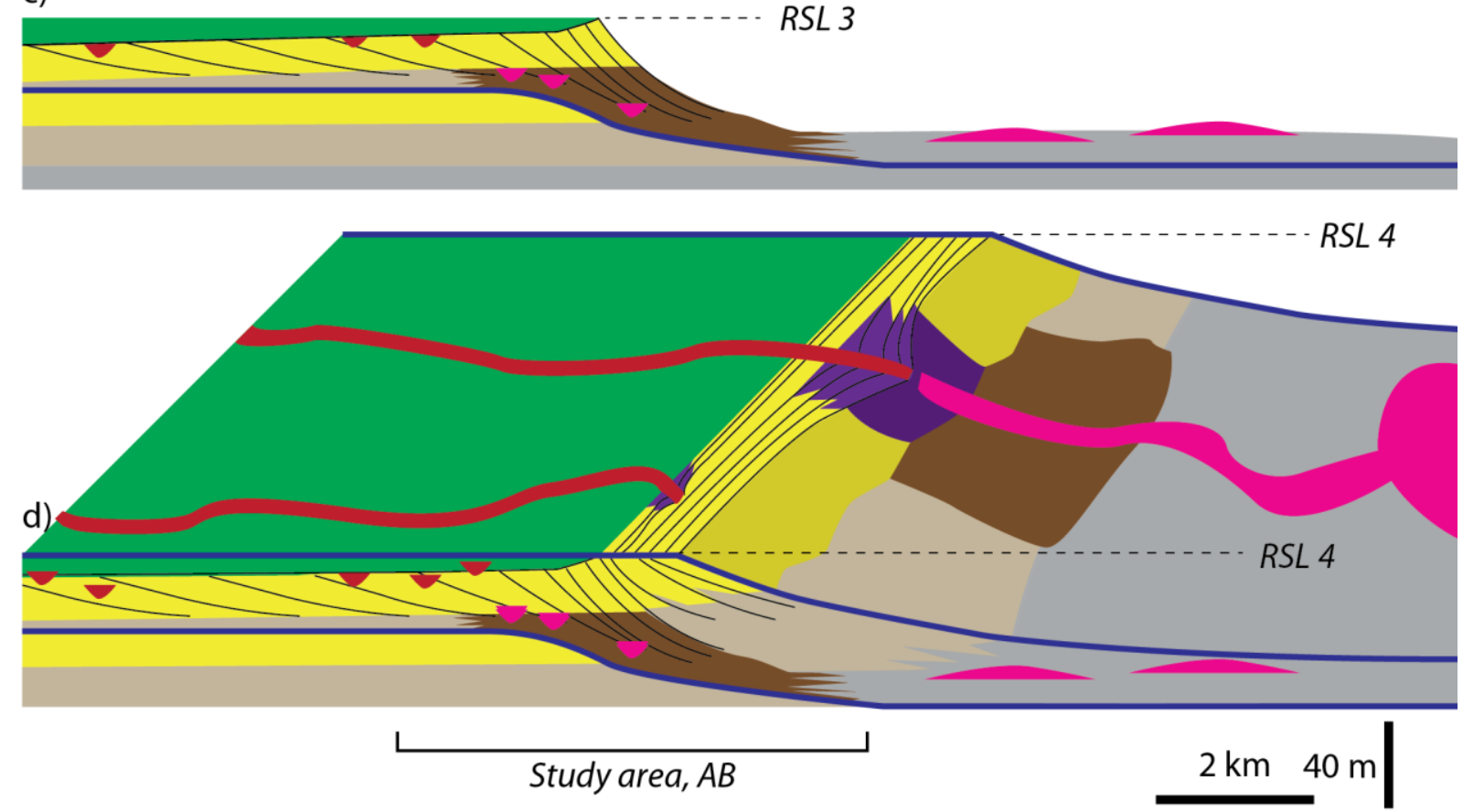

Fig. 11. Evolution of shoreface during progradation over inherited bathymetry. (a) Progradation and transgression of an earlier parasequence creates a shallow platform and a bathymetric break. (b) Rapid progradation under slowly rising sea level. Gentle seawards thickening of the parasequence is followed by a comparable thickening of the shoreface element until the water depth in front of the 
shoreline is equal to the average storm-weather wave-base. Further relative sea-level rise will lead to the development of offshore transition deposits below the shoreface. (c) Progradation slows down when the shoreline reaches deep water seawards of the pinch-out of the underlying parasequence because a larger accommodation must be filled per time unit. Increased steepness due to deeper water increases the probability for hyperpycnal flows to form near deltas. Erosion due to these currents may lead to development of erosive offshore transition deposits. (d) Delta avulses away from the studied line (or the subaqueous transport is so effective that the previous topography becomes filled in). Finally, the system is transgressed. The area labelled 'Study area, $A B$ ' has had a similar evolution to the profile A-B in Figure 6.

\section{Influence of inherited bathymetry}

The bathymetry of a typical progradational clastic shelf is smooth and dipping seaward at c. $0.02^{\circ}$ (Hampson 2010). A very low seaward dip is also typical for an aggradational coastal plain. The dip of the shoreface is generally steeper (c. 0.5 degrees from observed clinoforms in the Kenilworth K4, Fig. 6). Parasequence boundaries are associated with a rapid transgression which displaces the shoreline several kilometers landward. The bathymetry on the front of the transgressed parasequence may be preserved during such a transgression. It would then form a local bathymetric step on the shelf in front of the new parasequence (Fig. 11a,b). This step is called a "platform break". The following parasequence will prograde rapidly across the shallow-water platform landward of the platform break because of the limited accommodation space. The progradation rate will decrease once the shoreline system reaches the deep water on the seaward side of the platform break, because a larger accommodation space has to be filled with sediment in order to prograde.

As shorelines prograde into deeper water, delta front slopes steepen, and gravity-driven masstransport becomes more important (Postma 1990, Bhattacharya and MacEachern, 2009; Fig. 11c). Subaqueous channels are not observed where the shorefaces prograded on the shallow-water platform above the preceding shoreface (Fig. 11b), only in parts of parasequences which prograded to or beyond the platform break (Figs. 1, 2, 11c). Bhattacharya and MacEachern (2009) note that river-fed hyperpycnal plumes require a slope of more than $0.7^{\circ}$ to form. Slopes as steep as this are commonly not developed seaward of a platform break, but do occur near the platform break (Fig. 11).

\section{Modern and ancient analogs}

Two studies illustrate how the subaqueous channels could be related to gutter casts. Amos et al. (2003) observed a series of gutters (small channels less than $3 \mathrm{~m}$ wide and $0.5 \mathrm{~m}$ deep, and more than $40 \mathrm{~m}$ long) within irregular shore-normal channels, up to $1 \mathrm{~m}$ deep and $50 \mathrm{~m}$ wide, offshore Sable Island on the Scotian Shelf, Canada. These were interpreted to form by scour of turbidity currents during a downwelling event caused by coastal set-up during strong onshore winds. The geometries observed offshore Sable Island are a potential modern analogue for the OTZe deposits. However, OTZe deposits and subaqueous channels in the study dataset occur locally, not along the entire shoreline, which would be expected if storm-generated downwelling-events were the primary mechanism for generating the erosive turbidity currents.

Elliott (2000) attributed the formation of 1-45 m wide, 0.5-3 m deep and 5-25 m or more long "megaflutes" in the Ross Formation (Upper Carboniferous, Ireland) to erosion by bypassing turbidity 
currents. These megaflutes are commonly filled with mud, in contrast to the gutters in the OTZe of the K4 and G2 parasequences, which are commonly filled with hummocky-cross-stratified sandstone. However, the megaflutes in the Ross formation were cut and filled well below storm wave-base, while the gutters observed in this study formed above storm wave-base.

\section{Distribution of OTZe in the Book Cliffs}

To test the hypothesis that erosive offshore transition develops as a result of erosion by down-slope gravity transport by turbidity currents that preferentially develop as shorelines prograde into deeper water, all reported occurrences of gutter casts (SC5, K4, S2, and G2, this paper; "upper Aberdeen" in Coal Creek Canyon and D1 in Floy Wash, Pattison et al. 2007; D2 in Calf Canyon, Van Wagoner 1995), subaqueous channels (this paper, Pattison et al. 2007) and turbidite lobe deposits (Hampson, 2010) in the Book Cliffs have been plotted together with shoreline trajectories (from Hampson, 2010 and Hampson et al. 2011) for each parasequence in the Star Point Sandstone and Blackhawk Formation (Fig. 12).

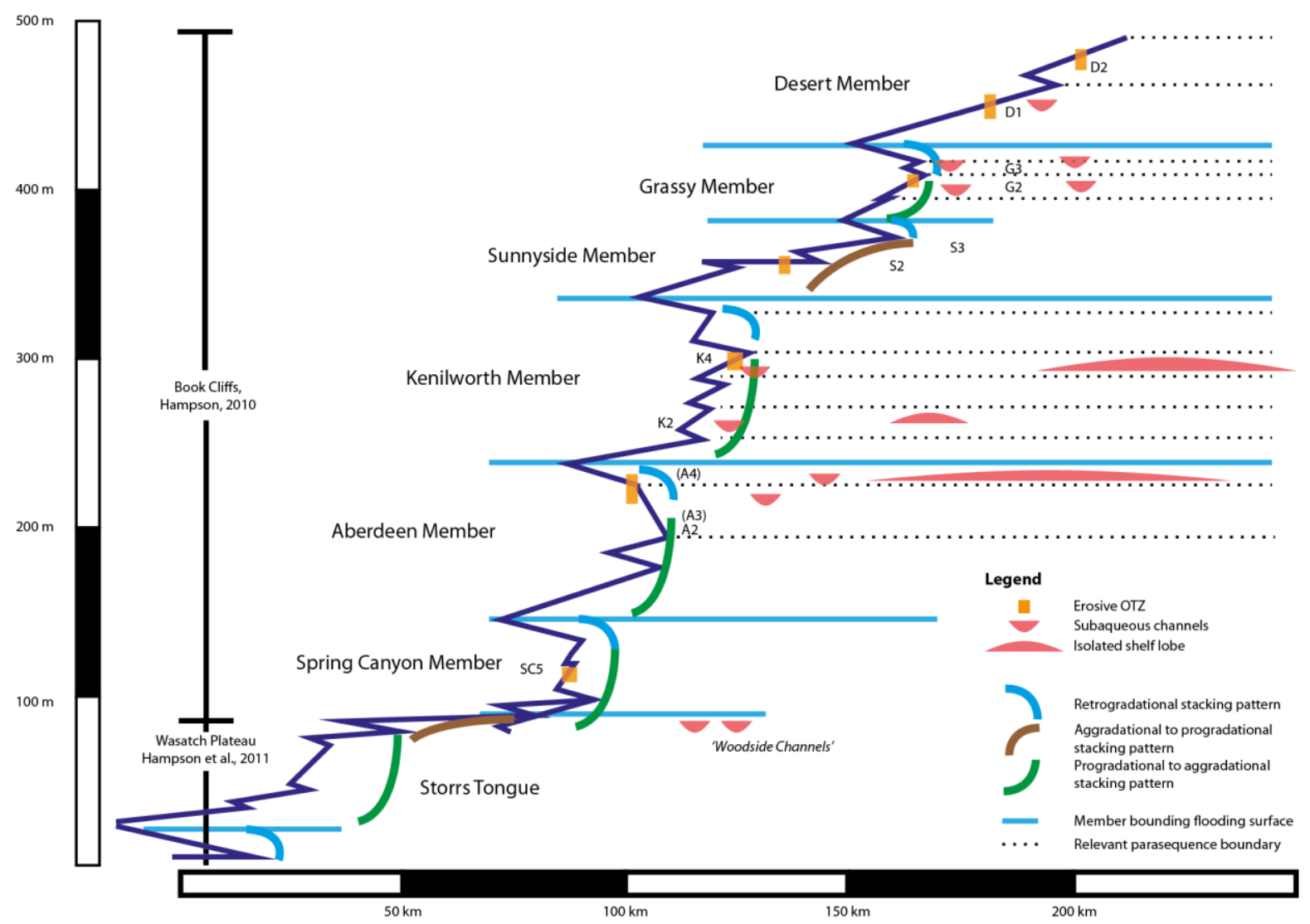

Fig. 12. Parasequence-scale shoreline trajectories of the Blackhawk and Star Point formations (from Hampson 2010 and Hampson et al. 2011), plotted together with reported occurrences of erosive offshore transition-zone deposits (OTZe), subaqueous channels and shelfal gravity-flow deposits (from Pattison et al. 2007 and Hampson 2010). Erosive offshore transition-zone deposits appear to be developed in areas where shorefaces prograded across bathymetric breaks caused by the seawards pinch-out of the preceding shoreface, and are associated with subaqueous channels, significant basinal gravity-flow deposits and significant subaqueous topography. 
Gutter casts and erosive offshore transition-zone deposits have been observed locally in all members of the marine Blackhawk Formation (Fig. 12), and subaqueous channels have been observed in all members except the Sunnyside and Spring Canyon.

Turbidite lobes are not developed at the bases of members, when shorelines would be prograding in shallow water. Likewise, the parasequences where the erosive offshore transition elements have been observed have all prograded into deep water basinwards of the underlying parasequences in the parasequence set. However, OTZe deposits are only present locally in each of the parasequences, suggesting that it is caused by local conditions. The most likely candidate to provide widely spaced, localized variations, are deltas prograding into deeper water, which occur locally within the shoreline systems surrounded by strandplains which are mostly fed by longshore drift. Pattison et al. (2007) proposed that gutters in proximal areas could be used to predict down-dip occurrence of turbidite lobes. The findings in this paper serve to corroborate this hypothesis. It follows from this model that greatest potential for shoreline systems to prograde into deep water occurs towards the top of progradationally stacked parasequence sets. The greatest volumes of basinal gravity flow deposits and OTZe deposits would therefore be expected to coincide with the maximum progradational extent of progradationally stacked parasequence sets.

The proposed model provides a way to predict the localized occurrence of OTZe deposits. Given that distributary channels and fluvial input points can be imaged in high-quality seismic amplitude maps (Jackson et al. 2010), and that parasequences and their pinch-out can be mapped from well log correlations, such a model provides a method to predict areas of locally enhanced effective vertical permeability due to the presence of OTZe rather than the more common OTZt deposits.

\section{Conclusion}

1. Erosive offshore transition deposits are observed locally in all members of the Blackhawk Formation in central Utah. Erosive offshore transition deposits are highly amalgamated, contain large gutter casts and have erosive, undulating sandstone bed geometries. Tabular offshore transition deposits have tabular, generally non-erosive sandstone beds and continuous mudstone beds separating sandstone beds. The two types of offshore transition are very different when seen in cross-section at outcrop, but will be nearly identical in vertical logs or core. Tabular offshore transition deposits are most common, but erosive offshore transition deposits occur in areas that may be more than $6 \mathrm{~km}$ down depositional dip and $2 \mathrm{~km}$ along depositional strike.

2. Upscaled reservoir models of erosive and tabular offshore transition zone deposits show that permeability is nearly identical in the horizontal directions, but that the vertical permeability is greater by a factor of 10 - 2 for erosive offshore transition deposits than for the tabular type, and that the difference decreases with increasing shale fraction.

3. Preliminary investigation shows that erosive offshore transition deposits are more likely to form close to subaqueous channels, which form in or seawards of fluvial input points that are close to a bathymetric break.

4. Bathymetric breaks may form in the basin when parasequences are transgressed rapidly enough to preserve the depositional slope from the shoreline to the base of the lower shoreface. The subsequent shoreface will prograde rapidly over the platform on top of the preceding shoreface, but 
slow down when it reaches the platform break. When it reaches the platform break, clinoforms steepen and the probability of generating hyperpycnal flows increase. These hyperpycnal flows may erode the substrate, creating erosional hollows which subsequently fill with sand as a result of wavedriven sand transport.

\section{Acknowledgements and Funding}

Funding for this study was provided from the Research Council of Norway (Petromaks project 193059) and the FORCE Safari project. The helicopter-LiDAR data was collected by J. Valet and S. Pitiot of Helimap

System SA. Riegl LMS GmbH is acknowledged for software support for the outcrop models, and ROXAR is acknowledged for use of their RMS reservoir modelling package. A. Rittersbacher is acknowledged for processing the heli-LiDAR model. The first author would like to thank O. S. MulelidTynes and G. Henstra for assistance in the field and for valuable discussions. G. Hampson is thanked for insightful comments that significantly improved this manuscript.

\section{References}

Ainsworth, R. B. \& Pattison, S. A. J. 1994. Where have all the lowstands gone? Evidence for attached lowstand systems tracts in the Western Interior of North America. Geology, 22, 415-418.

Ainsworth, R. B. 2005. Sequence stratigraphic-based analysis of reservoir connectivity: influence of depositional architecture - a case study from a marginal marine depositional setting. Petroleum Geoscience, 11, 257-276.

Ainsworth, R. B., Vakarelov, V. K. \& Nanson, R. A. 2011.Dynamic spatial and temporal prediction of changes in depositional processes on clastic shorelines: Toward improved subsurface uncertainty reduction and management. AAPG Bulletin, 95, 267-297.

Amos, C. L., Li, M. Z., Chiocci, F. L., La Monica, G. B., Cappucci, S., King, E. H. \& Corbani, F., 2003. Origin of shore-normal channels from the shoreface of Sable Island, Canada. Journal of Geophysical Research, 108, 39-1 - 39-16.

Bellian, J. A., Kerans, C. \& Jennette, D. C. 2005. Digital outcrop models: Applications of terrestrial scanning LIDAR technology in stratigraphic modeling: Journal of Sedimentary Research, 75, 166-176.

Bhattacharya, J. P. \& Giosan, L. 2003. Wave-influenced deltas: Geomorphical implications for facies reconstruction. Sedimentology, 50, 187-210.

Bhattacharya, J. P. \& MacEachern, J. A. 2009. Hyperpycnal rivers and prodeltaic shelves in the Cretaceous Seaway of North America. Journal of sedimentary Research, 79, 184-209.

Bhattacharya, J. P. 2011. Practical problems in the application of the sequence stratigraphic method and key surfaces: integrating observations from ancient fluvial-deltaic wedges with Quaternary and modelling studies. Sedimentology, 58, 120-169. 
Brenchley, P. J., Romano, M. \&Gutiérrez-Marco, J. C. 1986. Proximal and distal hummocky crossstratified facies on a wide Ordovician Shelf in Iberia. In: Knight, R. J. and McLean, J. R. (eds) Shelf Sands and Sandstones. Canadian society of Petroleum Geologists Memoir II, 251-255.

Buckley, S. J., Vallet, J., Braathen, A. \& Wheeler, W. 2008a. Oblique helicopter-based laser scanning for digital terrain modelling and visualisation of geological outcrops: Int Arch Photogrammetry, Remote Sens Spatial Inform Sci, 37, 493-498.

Buckley, S.J., Howell, J. A., Enge, H. D. \& Kurz, T. H. 2008b. Terrestrial laser scanning in geology: data acquisition, processing and accuracy considerations. Journal of the Geological Society, 165, 625-638.

Buckley, S. J., Enge, H. D., Carlsson, C. \& Howell, J. A. 2010. Terrestrial Laser Scanning for use in Virtual Outcrop Geology. The Photogrammetric Record, 25, 225-239.

Bullimore, S. A. \& Helland-Hansen, W. 2009. Trajectory analysis of the lower Brent Group (Jurassic), Northern North sea: contrasting depositional patterns during the advance of a major deltaic system. Basin Research, 21, 559-572.

Charvin, K., Hampson, G. J., Gallagher, K. L. \& Labourdette, R. 2010. Intra-parasequence architecture of an interpreted asymmetrical wave-dominated delta. Sedimentology, 57, 760-785.

Clifton, H. E. 2006. A re-examination of facies models for clastic shorelines. In: Posamentier, H. W. \& Walker, R. G. (eds) Facies models revisited. SEPM Special Publication 84, 293-337.

Collinson, J. D., Mountney, N. P. \& Thompson, D. B. 2006. Sedimentary structures. Harpenden, Terra Publishing, $296 \mathrm{p}$.

Davies, R., Diessel, C., Howell, J., Flint, S. \& Boyd, R. 2005. Vertical and lateral variations in the petrography of the Upper Cretaceous Sunnyside coal of eastern Utah, U.S.A. - Implications for the recognition of high-resolution accommodation changes in paralic coal seams. International Journal of Coal Geology, 61, 13-33.

Davies, R., Howell, J., Boyd, R., Flint, S. \& Diessel, C. 2006. High-resolution sequence-stratigraphic correlation between shallow-marine and terrestrial strata: Examples from the Sunnyside Member of the Cretaceous Blackhawk Formation, Book Cliffs, eastern Utah. AAPG Bulletin, 90, 1121-1140.

Dott, R. H. \& Bourgeois, J. 1982. Hummocky stratification: Significance of its variable bedding sequences. Geological Society of America Bulletin, 93, 663-680.

Dumas, S. \& Arnott, R.W.C. 2006. Origin of hummocky and swaley cross-stratification- The controlling influence of unidirectional current strength and aggradation rate. Geology 34, 1073-1076.

Eide, C. H., Howell, J. A. \& Buckley, S. J. 2014. Distribution of discontinuous mudstone beds within wave-dominated shallow-marine deposits: Star Point Sandstone and Blackhawk Formation, Eastern Utah, USA. AAPG Bulletin, 98, 1401-1429.

Elliott, T. 1978. Deltas. In: Reading H. G. (ed) Sedimentary Environments and Facies 2, 113-154.

Elliott, T. 2000. Megaflute erosion surfaces and the initiation of turbidite channels. Geology, 20, 119122. 
Enge, H. D., Buckley, S. J., Rotevatn, A. \& Howell, J. A. 2007. From outcrop to reservoir simulation model: Workflow and procedures. Geosphere, 3, 469-490.

Fouch, T. D., Lawton, T. F., Nichols D. J., Cashion W. B. \& Cobban, W. A. 1983. Patterns and timing of synorogenic sedimentation in Upper Cretaceous rocks of central and northeast Utah. In Reynolds M. W. \& Dolly E. D. (eds) Mesozoic Paleogeography of the West-Central United States, 305-336.

Galloway, W. E., Ganey-Curry, P.E., Li, X. \& Butler, R. T. 2000. Cenozoic depositional history of the Gulf of Mexico basin. AAPG Bulletin, 84, 1743-1774.

Hadley, D. F. \& Elliott, T. 1993. The sequence stratigraphic significance of erosive-based shoreface sequences in the Cretaceous Mesaverde Group of northwestern Colorado. In: Posamentier, H. W., Summerhayes, C. P., Haq, B. U. \& Allen, G. P. (eds) Sequence stratigraphy and Facies Associations. International Association of Sedimentologists, Special Publication, 18, 521-535.

Hampson, G. J. 2000. Discontinuity surfaces, clinoforms, and facies architecture in a wave-dominated shoreface-shelf parasequence. Journal of Sedimentary Research, 70, 325-340.

Hampson, G. J. 2010. Sediment dispersal and quantitative stratigraphic architecture across an ancient shelf. Sedimentology, 57, 96-141.

Hampson G. J. \& Storms, J. E. A. 2003. Geomorphical and sequence stratigraphic variability in wavedominated, shoreface-shelf parasequences. Sedimentology, 50, 667-701

Hampson, G. J. \& Howell, J. A. 2005. Sedimentologic and geomorphic characterization of ancient wave-dominated deltaic shorelines: Upper Cretaceous Blackhawk Formation, Book Cliffs, Utah, U.S.A. SEPM Special Publication, 83, 133-154.

Hampson, G. J., Royhan Gani, M. , Sharman, K. E., Irfan, N. \& Bracken, B. 2011. Along-strike and down-dip variations in shallow-marine sequence stratigraphic architecture: Upper Cretaceous Star Point Sandstone, Wasatch Plateau, Central Utah, U.S.A. Journal of Sedimentary Research, 81, 159184.

Hampson, G. J., Royhan Gani, M., Sahooo, H., et al. 2012. Controls on large-scale patterns of fluvial sandbody distribution in alluvial to coastal plain strata: Upper Cretaceous Blackhawk Formation, Wasatch Plateau, Central Utah, USA. Sedimentology, 59, 2226-2258.

Hampson, G. J., Jewell, T. O., Irfan, N., Royhan Gani, M. \& Bracken, B. 2013. Modest change in fluvial style with varying accommodation in regressive alluvial-to-coastal-plain wedge: Upper Cretaceous Blackhawk Formation, Wasatch Plateau, Central Utah, U.S.A. Journal of Sedimentary Research, 83, 145-169.

Haq, B.U., Hardenbol, J. \& Vail, P.R. 1988. Mesozoic and Cenozoic chronostratigraphy and eustatic cycles. In: Wilgus, C.K., Hastings, B. J., Posamentier, H., Van Wagoner, J. C., Ross, C. A. \& Kendall C. G. St. C. ( eds.) Sea-level change: An integrated approach. Society of Economic Paleontologists and Mineralogists Special Publication 42, 71-108.

Héquette, A. \& Hill, P. R. 1993. Storm-generated currents and offshore sediment transport on a sandy shoreface, Tibjak Becah, Canadian Beaufort Sea. Marine geology, 113, 283-304. 
Higgs, R., 2004. Ross and Bude formations (Carboniferous, Ireland and England): Reinterpreted as lake-shelf turbidites. Journal of Petroleum Geology, 27, 47-66.

Hodgetts, D., Imber, J., Childs, C. et al. 2001. Sequence stratigraphic responses to shoreline perpendicular growth faulting in shallow marine reservoirs of the Champion field, offshore Brunei Darussalam, South China Sea. AAPG Bulletin, 85, 433-457.

Holden, L., Hauge, R.,Skare, Ø. \& Skorstad, A. 1998. Modeling of Fluvial Reservoirs with Object Models. Mathematical Geology, 30, 473-496.

Howell, J. A. \& Flint, S. 2003, Siliciclastics case study: the Book Cliffs. In: Coe, A. (ed) The Sedimentary Record of Sea-Level Change. Cambridge, U.K., Cambridge University Press, 135-208.

Howell, J. A., Skorstad, A., MacDonald, A., Fordham, A., Flint, S., Fjellvoll, B. \& Manzocchi, T. 2008. Sedimentological parameterization of shallow-marine reservoirs. Petroleum Geoscience, 14, 17-34.

Husmo, T., Hamar, G. P., Høiland, O., Johannessen, J. P., Rømuld A., Spencer, A. M. \& Titterton, R. 2003. Lower and Middle Jurassic. In: Evans D., Graham C., Armour, A. \& Bathurst, P. (eds) The Millennium Atlas: Petroleum geology of the central and northern North Sea. London, Geological Society, 129-156.

Jackson, C. A.-L., Grunhagen, H., Howell, J. A., Larsen, A. L., Andersson, A., Boen, F. \& Groth, A. 2010. 3D seismic imaging of lower delta-plain beach ridges: lower Brent Group, northern North sea. Journal of the Geological Society, 167, 1225-1236.

Kauffman , E. G. \& Caldwell, W. G. E. 1993. The Western Interior Basin in space and time. In: W. G. E. Caldwell \& Kauffman E. G. (eds). Evolution of the Western Interior Basin. Geological Association of Canada, Special Paper 39, 1-30.

MacDonald, A. C. \& Aasen, J. O. 1994. A prototype procedure for stochastic modeling of facies tract distribution in shoreface reservoirs. In: Yarus, J. M. \& Chambers R. L. (eds) Stochastic modeling and geostatistics. AAPG Computer Applications in Geology 3, 91-108.

Manzocchi, T., Carter, J.N., Skorstad, A. et al. 2008. Sensitivity of the impact of geological uncertainty on production from faulted and unfaulted shallow-marine oil reservoirs: objectives and methods. Petroleum Geoscience, 14, 3-15

Myrow, P.M. \& Southard, J.B., 1996. Tempestite deposition. Journal of Sedimentary Research, 66, 875-887.

O'Byrne, C. J. \& Flint, S. 1995. Sequence, Parasequence and Intraparasequence Architecture of the Grassy Member, Blackhawk Formation, Book Cliffs, Utah, USA. In: Van Wagoner, J. C., Mitchum, R. M., Campion, K. M., and Rahmanian, V. D. (eds.) Sequence Stratigraphy of Foreland Basin Deposits: Outcrop and Subsurface Examples from the Cretaceous of North America. AAPG Memoir, 64, 225256.

Olariu, C. \& Bhattacharya, J. P. 2006. Terminal distributary channels and delta front architecture of river-dominated delta systems. Journal of Sedimentary Research, 76, 212-233. 
Pattison, S. A. J. 1995. Sequence Stratigraphic Significance of Sharp-Based Lowstand Shoreface Deposits, Kenilworth Member, Book Cliffs, Utah. AAPG Bulletin, 79, 44-462.

Pattison, S. A. J. 2005a. Storm-influenced prodelta turbidite complex in the lower Kenilworth Member at Hatch Mesa, Book Cliffs, Utah, U.S.A.: Implications for shallow-marine facies models. Journal of Sedimentary Research, 75, 420-439.

Pattison, S. A. J. 2005b. Isolated highstand shelf sandstone body of turbiditic origin, lower Kenilworth Member, Cretaceous Western Interior, Book Cliffs, Utah, USA. Sedimentary Geology 177, 131-144.

Pattison, S. A. J., Ainsworth, R. B. \& Hoffman, T. A. 2007. Evidence of across-shelf transport of finegrained sediments: turbidite-filled shelf channels in the Campanian Aberdeen Member, Book Cliffs, Utah, USA. Sedimentology, 54, 1033-1063.

Plint, A.G. 1991. High-frequency relative sea-level oscillations in Upper Cretaceous shelf clastics of the Alberta foreland basin: Possible evidence for a glacio-eustatic control?. In: Macdonald, D. I. M. (ed) Sedimentation, Tectonics and Eustasy: Sea-level Changes at Active Margins. International Association of Sedimentologists Special Publication, 12, 409-428.

Postma, G. 1990. An analysis of the variation in delta architecture. Terra Nova, 2, 124-130.

Pringle, J. K., Howell, J. A., Hodgetts, D., Westerman, A. R. \& Hodgson, D. M. 2006. Virtual outcrop models of petroleum reservoir analogs: A review of the current state-of-the-art. First Break, 24, 3342.

Rittersbacher, A., Buckley, S. J., Howell, J. A., Hampson, G. J. and Vallet J. 2013. Helicopter-based laser scanning: a method for quantitative analysis of large-scale sedimentary architecture. In: Martinius, A. W., Howell, J. A. \& Good, T. (eds) Sediment-Body Geometry and Heterogeneity: Analogue Studies for Modelling the Subsurface. Geological Society, London, Special Publications, 387.

Rittersbacher, A., Howell, J. A. \& Buckley, S. J. 2014. Analysis of fluvial architecture in the Blackhawk Formation, Wasatch Plateau, Utah, using large 3D photorealistic models. Journal of Sedimentary Research, 84, 72-87.

Storms, J. E. A. \& Hampson, G. J. 2005. Mechanisms for forming discontinuity surfaces within shoreface-shelf parasequences: sea level, sediment supply or wave regime?. Journal of Sedimentary Research, 75, 67-81.

Sømme, T. O., Howell, J. A., Hampson, G. J. \& J. E. A. Storms, 2008. Genesis, architecture, and numerical modeling of intra-parasequence discontinuity surfaces in wave-dominated deltaic deposits: Upper Cretaceous Sunnyside Member, Blackhawk Formation, Book Cliffs, Utah, U.S.A. In: Hampson, G. J., Steel, R. J, Burgess, P. M. \& Dalrymple, R. W. (eds) Recent advances in models of siliciclastic shallow-marine stratigraphy. SEPM special publication, 90, 421-441.

Taylor, A. M., \& Goldring, R., 1993. Description and analysis of bioturbation and ichnofabric. Geological Society of London, Journal, 150, 141-148.

Taylor, D. R. \& Lovell, R. W. W. 1995. High-frequency sequence stratigraphy and paleogeography of the Kenilworth Member, Blackhawk Formation, Book Cliffs, Utah, USA. In: J. C. Van Wagoner \& 
Bertram, G. T. (eds) Sequence Stratigraphy of Foreland Basin Deposits: Outcrop and Subsurface Examples from the Cretaceous of North America. AAPG Memoir, 64, 257-275.

Vallet, J. \& Skaloud J., 2004. Development and experiences with a fully-digital handheld mapping system operated from a helicopter. International Archives of the Photogrammetry, Remote Sensing and Spatial Information Sciences, 35, Part B5, 1-6.

Van Wagoner, J. C., Mitchum, R. M., Campion, K. M. \& Rahmanian, V. D. 1990. Siliciclastic sequence stratigraphy in well logs, cores and outcrops: Concepts for high-resolution correlation of time and facies: AAPG Methods in Exploration Series 7, $55 \mathrm{p}$.

Van Wagoner, J.C., 1995 Sequence stratigraphy and marine to nonmarine facies architecture of foreland basin strata, Book Cliffs, Utah, U.S.A. In: Van Wagoner, J. C. \& Bertram, G. T. (eds) Sequence Stratigraphy of Foreland Basin Deposits. Outcrop and Subsurface Examples from the Cretaceous of North America, AAPG Memoir 64, 257-275.

Wen X.-H., \& Gomez-Hernandez, J. J. 1996. Upscaling hydraulic conductivities in heterogeneous media - an overview. Journal of Hydrology, 183, ix-xxxiii.

Went, D. J., Hamilton, R. V., Platt, N. H. \& Underhill, J. R. 2013. Role of forced regression in controlling Brent Group reservoir architecture and prospectivity in the northern North Sea. Petroleum Geoscience, 19, 307-328.

Young, R. G. 1955. Sedimentary facies and intertonguing in the Upper Cretaceous of the Book Cliffs, Utah-Colorado. Bulletin of the Geological Society of America, 66, 177-202. 